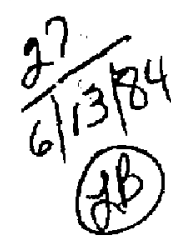

\title{
- \\ Evaluation of Nonaqueous Processes for Nuclear Materials
}

Task Report to the Long-Range

Planning Committee

Burdon C. Musgrave

John Z. Grens

James B. Knighton

Melvin S. Coops

December 1983

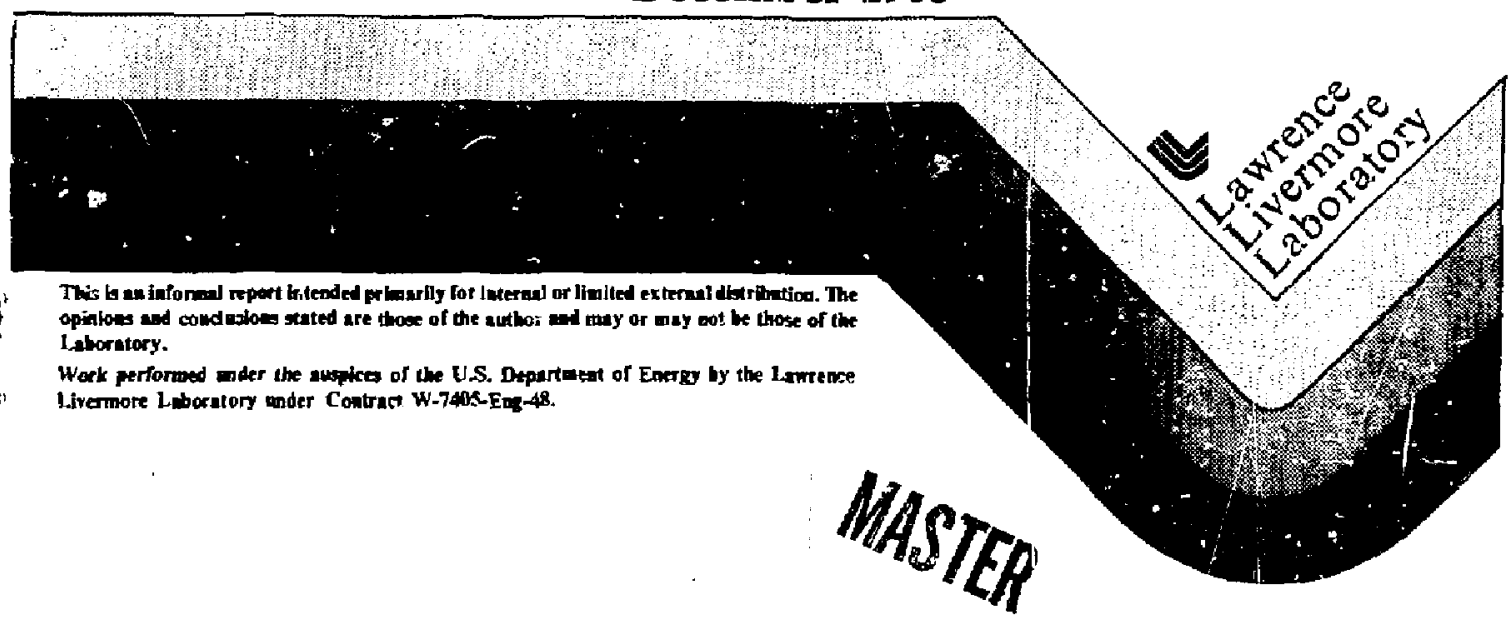

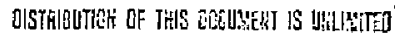




\section{EXECUTIVE SUMMARY}

A working group was assigned the cask of evaluating the status of nonaqueous processes for nuclear materials and the prospects for successful deployment of these technologies in the future. In the initial evaluation, we narrowed the study to the pyrochemical/pyrometailurgical processes closely related to the processes used for purification of plutonium and its conversion to metal. We reviewed the status of the chemistry and process hardware and evaluated the development needs in both chemistry and process equipment technology. Finally, we established the requirements for successful deployment of this technology.

We evaluated the status of the technology along three lines: (1) we first examined the current applications for completeness, (2) we then attempted to construct elosed-cycle flow sheets for several proposed applications, (3) and finally we reviewed the status of technical development and future development needs for general applications. Using these three evaluations, we constructed three different perspectives that together present a clear picture of how complete the technical development of these procesges is.

1. Current applications. The electrorefining and metal reduction steps work well, although not $100 \%$ reliably. The metal rings pictured as the expected product are sometimes not produced, with the resul.t that the platonium is eithex in the starting irapure anode "heel" or dispersed in the salt phase. In either case, there is a significant loss of time and process efficiency. On a systematic basis, however, these procesues work satisfactorily most of the time. Salt extraction of anericium from stockpile return plutonium generates purified plutonium as intended, but also produces a salt waste that contains significant quantities of plutonium. ${ }^{2}$ other currently unzeprocessible wastes are also produced at times.

2. Flow sheets. We examined three flow sheets to assess the completeness of their technical work. These were (a) the metal processing lines for special isotope separation (SIS) support at LLN, and for the Rocky Flats metal rework line, (b) a proposed process for Zero Power Plutonium Reactor (ZPPR) fuel return, and 
(c) the rework of Pu-concaining salts accurulated at the Rocky Flats Plant (RFP). While all flow sheets are extremely tentative, data are available for the major steps of the mainline processes. Few data are available for the side streams required to close the process loops, but reasonable assumptions have areated possible flow sheets. Limited information is used to predict the behavior of trace components in recyeled streams. Major additional conponents that might be introduced in salt or ash treatment are not considered to present serious problens. Nonaqueous recycle loops are at present being developed for salt and electrorefining heels to avoid buildup of massive quantities of thes $\epsilon_{\text {materials. Recycle is }}$ possible by aqueous means, but that choice would reduce the apparent advantages of nonaqueous processes resulting from low waste generation and reduced process steps.

3. Development needs. A summary of the development needs for the RFP applications is given below; ${ }^{3}$ a more detailed review is provijed in Appendix A to this report. In general, development needs are indjcated by the absence of datz that are required to construct flow sheets for proposed process options. These development needs are extensions of the existing cheraistry bases and include the following:

a. Decermination of additional distribution coefficients

b. Extension of separation/reaction studies to additional binary and ternary salt systems

c. Determination of reaction rate data for process steps

d. Development of recycle and/or cleariup processes for byproducts and waste streams

e. Determination of the behavior of minor components on extensive recycle

f. Determination of the purity requirenents for starting materials

g. Improvement of most hardware operations.

Eleven general conclusions are supported by the detailed study.

1. The chemistry of these processes is simple. Much of the needed technical development effort would be expenied on basic chemistry. 
2. The methodology is effective where it is applied with glovebox operations. For higher throughputs and working with highly radioactive materials, considerable hardware and operations development will be required.

3. Most mainline steps shown in the flow sheets have been demonstrated at' laboratory scale or larger.

4. Additional chemical studies are required on solubilities, extraction into mixed molten salts, phase diagrams in complex systems, behavior of minor components (impurities), viscosities, densities, and kinetics in all process steps.

5. Process steps in current use are workable, but have not been optimized. The work needed for some improvements has been identified.

6. Comparison of the process waste generated by aqueous vs nonaqueous processes is exaggerated by looking only at the intermediate form. Mast of the water in the aqueous streams will eventually be released as water vapor. All final materials from nonaqueous streams mus be disposed of as transuranic or higher active wastes.

7. Line-generated wastes have not been completely defined for the proposed processes.

8. None of the processes in current usage is completely closed. Aqueous processes will be required for the indefinite future to support the pyro mainline systems to accomodats such problems as line-generated wastes and accident or spill cleanup wastes.

9. Applications of pyro technology to irradiated nuclear materials have not been demonstrated and will not be developed unless a significant technical requirement forces that development.

10. Process hardware (technology) development is required for both cold and highly radinactive process applications. This will include mixers for materials of greatly different densities, phase separation techniques, pusps, controls, valves, and sensors for temperature, density, composition, etc.

11. Comparison of the pyro flow sheets with purex flow sheets for current-generation LWR fuels ahows no net advantage for pyrc technology. 


\section{INTRODUCTION}

Nonaqueous processes have been used to produce metals and ceramic materials from the earliest recorded history, To the present, these processes have dominated the ore processing, glass, and ceramics industries.

It has long been recognized that nonaqueous processes have four significant potential advantages over aqueous processing for nuclear materials.

I. Radiation damage would be greatly reduced or nonexistent. Nonaqueous processes can provide for processing of higsly irradiated and/or short cooled fuel and special targets.

2. Considerably fewer steps are generally involved in the processes so that smaller spaces a.d reduced operating costs should result.

3. Higher density streams should also lead to smaller facilities with potentially lower capital costs.

4. The absence of moderators allows larger masses of fissionable materials to be handled.

Our study group was chartered by the Nuclear Energy Subcomittee of the IsPC t:o evaluace the status and potential of nonaqueous technology for potential applications to nuclear materials processing. We have identified two areas that have major importance for the defense and nuclear energy communities: (1) near-term problems in weapons materials production and (2) potential processes for recovery of resource materials from spent nuclear reactor fusls that include Naval propulsion, test, and demonstration reactors and nuclear electric power plant fuels. A wide spectrum of technologies ranging frow molten salts and molcen mecals to halide volatilizacion processes has been studied. Initial evaluations of the available technologies indicate that only those nonaqueous technologies collected under the general area of pyrochemical and pyrometallurgical processes hold significant potential for handling the problems of greatest near-term interest. Of these, the most successful applicatiens have been process.ss used in the purification, refining, and conversion of plutonium oxides to weapons-grade plutonium metal. Hecause of the short time avajiable for our study, we focused on these pyrocheristry steps as the basis for process flow sheets.

The use of nonaqueous processes for nuclesr material dates to the earliest production of uranium or plut.onium metal by reduction of the flutorides, oxides, or fused salts. This conversion cannot be done in aqueous 
solution. The capabilities in nonaqueous processes for purification and conversion of plutonium from oxides or salta to final weapong-grade metal have gradually been expanded. The fundamental cheraistry is as old as the bronze age; only the element being cast (Pu) is now.

Pyroprocesses have been proposed for all steps in the conversion of plutonium oxide and scrap to final weapons-grade plutonium metal. Several of these steps: caicination, calcium metal reduction, molten salt extraction, and electrorefining, have also been applied routinely at the Los Alamos National Laboratory. ${ }^{1}$ A brief description of thege procegses will be given in Chapter III.

The tools used in the glovebox operations are quite basic, nearly all standard hardware store or chemistry laboratory equipment: hammers, wrenches, screwdrivers, spatulss, etc. The lack of any major effort to improve the technology is apparently justified by the fact that the processes work for most purposes and shew clear advantages over the aqueous steps that they have displaced. At LARL, all pyro operatinns have been adapted to the sace furnace design. This consistency may be helpful to operating personnel as they move from one operation tr another. However, this uniformity may stifle attempts to improve equipment and operations.

We have examined the adequacy of the cheristry basis for the applicatione oi pyrotechnology to all proposed processes. As an aid to this evaluation, we looked both at the technology as it is now applied and at the completeness of flow sheets for each application. 


\section{SURMARY OF BASIC PROCESS STEPS}

Three near-term applications of pyrochemical technology to the processing of nuclear materials are described in the flow sheets acconpanying this report. These flow sheets have been constructed from six basic process steps:

1. Direct oxide reduction

2. Molten salt equilibration

3. Metal-metal equilibration

4. Metal distillation

5. Electrorefining

6. Pyroredox refining.

These six process steps can be combined into a large number of potential process flow sheets, ill of which share the advantages of pyrochemistry over conventional aqueors systems: very compact equipment, resistance to radiation damage, high density, and high concentration of in-process materials and products. These steps do not represent the total array of pyrochemical techniques available to the process designer. The very powerful "salt transport" process is not required by these applications, and its description is omitted, although it allows very elegant nuclear fuel reprocessing schertes to be designed. (Ryroredox is actually a special case of sait transport processes in generat.) Such operations are deferred to the realm of long-term applications.

\section{Direct Oxide Reduction}

The direct oxide reduction step employs the thermite reaction between $\mathrm{PuO}_{2}$ (or $\mathrm{UO}_{2}$ ) and $\mathrm{Ca}$ metal to produce $\mathrm{Pu}$ (or $\mathrm{U}$ ). The reaction is carried out at $835^{\circ} \mathrm{C}$ in the presence of a $\mathrm{CaCl}_{2}$ flux that dissolves the CaO product; excess $\mathrm{Ca}$ is added to drive the feaction to completion. Vigorous stirring is required to maintain intimate contact between the very dense actinide phases and the $\mathrm{Ca}$ and flux. This same density difference simplifies phase disengagement after the reaction is complete, when the actinides pasa to the next step and the salt moves to processing for recycle.

\section{Molten Salt Extraction}

Separations based on the transport of one or more components of a single-phase mixtura into a second, immiscible phase are comon to wany 
chemical processes. The transfer may or may not involve cherical reaction, but in all cases, an equilibrium distribtion is approached that is based on a minimum syster free energy.

In the molten salt extraction step, the first phase is molten $7 u$ with $241_{\mathrm{Am}}$ contaminant, and the second phase is a $\mathrm{NaCl}-\mathrm{CaCl}_{2}$ salt with a few percent $\mathrm{MgCl}_{2}$ added. Am is oxidized to $\mathrm{AmCl}_{3}$ by the $\mathrm{MgCl}_{2}$, and partitions to the salt phase; two sequential extractions remove about $90 \%$ of the Am. Small amounts of $\mathrm{PuCl}_{3}$ are also extracted, requiring a salt eleanup process to recover $P u$ from the salt phase. Mg metal from the reduction dissolves in the Pu and is removed by evaporation.

\section{Metal-Metal Extraction}

Separations can also be based on the partition of dissolved specics between two immiscible alloys. Distributions between the phases are governed by the net free energy of the reactants involved; however, because solvaticn reactions are generally less energetic, the partition achieved per contact stage is less dranatic than in oxidation-reduction separatious.

\section{Metal Distillation}

Metal distillation or vacuum evaporation is an effective pyrochemical process step because of the very large differences in vapor pressure available between many of the common metal solvents (zinc, calcium, magnesium) and actinide series elements at temperatures below about $800^{\circ} \mathrm{C}$. At temperatures around $1200^{\circ} \mathrm{C}$, separations such as Pu-Am become possible using fractional distillation techniques. While the vapor pressures of metals are reIl known, the activities of components of metallic solutions are often not availablen. Substantial work will be required if distillation is to be extended beyond simple binary systems.

\section{Electrorefining}

The eiectrorefining process step transports in-process metal through a salt phase under the influence of an electrical potential. The important feature in the process is the "buffering" of the salt phase with a substantial quantity of ions of the metal being purified. The excess of these inus forces the retention of impurities as metals and prevents their transport to the cathede and appearance in the product. 
When this technique is used for Pu purification, the Nac1-Kc1 salt phase is doped with PuCl $_{3}$, forcing imptrities more electropositive than Pu into the salt and leaving those less electropositive chan Pu as metals retained in the anode.

Additional processing of both residual anodes ("heels") and the Du-containing salt is necessary for a closed cycle. This processing is cutrently being practiced at LANL.

\section{Pyroredox Refining}

Pyroredox (and indeed, electrorefining) is a special case of the general class of pyrochemical operations terured "salt transport" processes. Pyroredox is considered an alternative to electrorefining as a final purification step in $\mathrm{Pu}$ recovery from scrap or material rework and is an appropriate technique for recycle of severely contaminated anode heels from electrorefining.

The pyroredox step for Pu occurs in two separate stages, The first is the oxidation of impure $\mathrm{Pu}$ with $\mathrm{ZnCl}_{2}$ to form $\mathrm{PuCl}_{3}$ and $\mathrm{Zn}$ metal. Impurities not oxidized by $\mathrm{ZnCl}_{2}$ are left in the $\mathrm{Zn}$ metal strean and are concentraced by evaporation of the $\mathrm{Zn}$. The $\mathrm{PuCl}_{3}$ is taken up by the salic phase.

In the second step, the $\mathrm{PuCl}_{3}$ is reduced with Ca metal, leaving aditional impurities as chloride salts. Salt and metal phase separations are accomplished by density differences, which are, as in the other salt-retal operations, quite targe.

The general class of salt transport process steps is too extensive to be covered here in any detail,* but all of the ateps involve the selective oxidation of one or more components of a metal solution into a salt phase and subsequent reduction into a second alloy. These techniques find application in proposed comercial nuclear fuel cycles and are beyond the scope of the near-term uses of pyrochemistry considered next.

\section{Near-Term Applications of Process Flow Sheets}

We have selected three near-terth applications of pyrochenical processing of nuclear materials as a part of this study. They may provide some larger scale experience in pyrochemistry and point to additional development needs

\footnotetext{
* A more extensive description is contained in Appendix A.
} 
that have not become apperent in bench scale work. Aqueour frocessing of nuclear material currently enjoys an experience advantage of literally thousands of man-years over pyrochemistry. To become truly competitive as a processing alternative, pyrochemiatry must develop a proven history in applipations for whish it has been selected because it has unique and very economically favorable advantagea over conventional methods.

We selected three applications:

1. Processing of Pu scrap and parts requiring rework

2. Processing of $\mathrm{ZPPR}$ fuel

3. Processing of salt residues.

In the balance of this section, we will discuss how the basic steps are combined into process flow sheets for these applications, as well as the cevelopments needed to implement each at pilot or larger scale,

\section{Processing of Pu Scrap and Parts Requiring Rework}

This application of pyrochemistry is in operation on a small scale at LANL and is being set up as a metal production line (MPL) For Triton parts at LLNL, Use of such processing at RFP would be attractive economically and should be seriously considered as a major pyrochemical demonstration.

In Fig. 1, which is drawn for pu scrap fed as oxide, the feed strean is sized and calcined in air at $800^{\circ} \mathrm{C}$ to provide input to the direct oxide reduction (DOR) step. Because scrap $P u$ is quite pyrophoric, it is normally burned in air to the oxide for safety and convenience in handling.

The DOR step is conducted as a batch operation in current bench-scale applications, and the maximum charge of $\mathrm{Pu}$ is limited to about $4 \mathrm{~kg}$ by criticality considerations. A difficulty here is the fact that the batch is cooled and the phases separated mechanically as solids using hand tools, a slow pracedure that atso necessitates the breakage of the Mgo crucible.

Development work is required to move the process to a fast-cycle batch type, with phase separations accomplished on molten materials in relatively long- 1 ived containers.

Both tantalum and tungsten show promise as crucible materials, but they may require doping the $\mathrm{CaCl}_{2}$ - $\mathrm{CaO}$ flux with $\mathrm{CaF}_{2}$ to lower the melting temperature to reduce corrosion and product contamination, Techniques for controlling the phass separation are also required. 
- Material

foursdry scrap, site returns, etc.

- Process

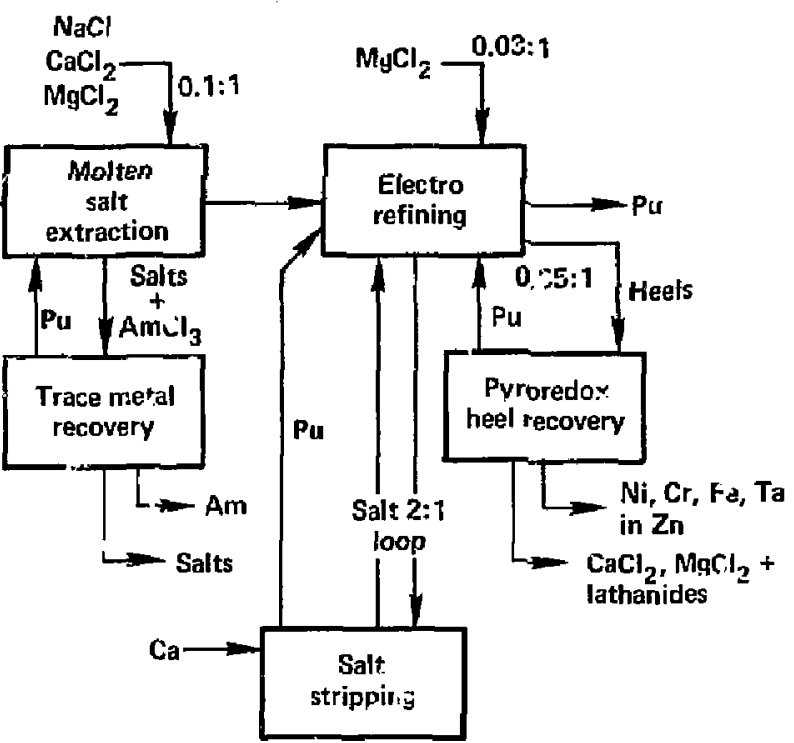

FIG. 1. Metal production line. 
Contising research is nacessary on the chemistry of the salt phase, particularly on the salt regeneration shown in the flow sheet that rechlorinates the $\mathrm{CaO}-\mathrm{CaCl}_{2}$ to $\mathrm{CaCl}_{2}$ with $\mathrm{Cr}_{2} \mathrm{I}_{2}$ or $\mathrm{KCl}$ and adsorbs che off gas in a $\mathrm{NaOH}$ scrubber. Some impurity buildup in the $\mathrm{CaCl}_{2}$ re-yele $\mathrm{Ca}_{\mathrm{ii}}$ be etpected, and the entire area of salt regenertion and recycle will reguire attertion if salt wastes are to be minimized. ilthough $\mathrm{Ca}$ recycla by electroiefining the $\mathrm{CaCl}_{2}$ is not shown on the flow sheet, it could reduce the amount of salt waste by closing the reagent systex around the jor step.

The Pu from the DOR step moves forward to the molten salt extractivi. where a $\mathrm{CaCl}_{2}-\mathrm{HgCl}_{2} \mathrm{NaCl}$ extraciant removes Am that has grown into the $\mathrm{Pu}$ during storage. The extraction, as previously described, is quite effective for An removal, but also removes some Pu from the main stream.

This step must be studied further to refine the distribution coefficients as functions of salt composition and to determine the behavior of ineoluble impurities and oxy-chlorides, as well as possible double salts.

Salt recycle is also a developrent task for this step, besause the salt product must be cleaned of $A m$ and $P u 2 n d$, as much as possibie, regenerated for: reuse. A second flow sheet, Fig. 2, shows the Pu recovery/salt cleanup operation for the metal production iine.

The first step in this process is another Dor step using Ca to reduce Am, $\mathrm{Pu}, \mathrm{Mg}$, and some $\mathrm{Na}$. The Na distills off during the reaction, while the $\mathrm{Mg}$ and any excess $\mathrm{Ca}$ are removed in 4 moderate-temperature distillation step at $800^{\circ} \mathrm{C}$ and the $\mathrm{Pu}$ and Am proceed to the third step, a metal distillation at $1200^{\circ} \mathrm{C}$. This teep is shown on Fig. 2 as two batch diatillations in series, with bottoms $(P u)$ recycled to the feed of the molten salt extraction step in the main process flow sheet.

Development work will be required an a recycle step to return the salt, siripjed of $\mathrm{Am}$ and $\mathrm{Pu}$, to the extraction step of the main process. A chlorination step, such as tiat used in DOR salt cleanup, will be necessary, and Ca must be bled off to maintain the proper salt ratio.

The Pu product frota the salt exsraccion is then cast into anodes for electrorefining. The electrorefining step produces a high-purity Pu realy for alloying and fabrication. Unfortunately, the electrorefining process also produces an anode residue or "heel" with an unacceptably high level of 


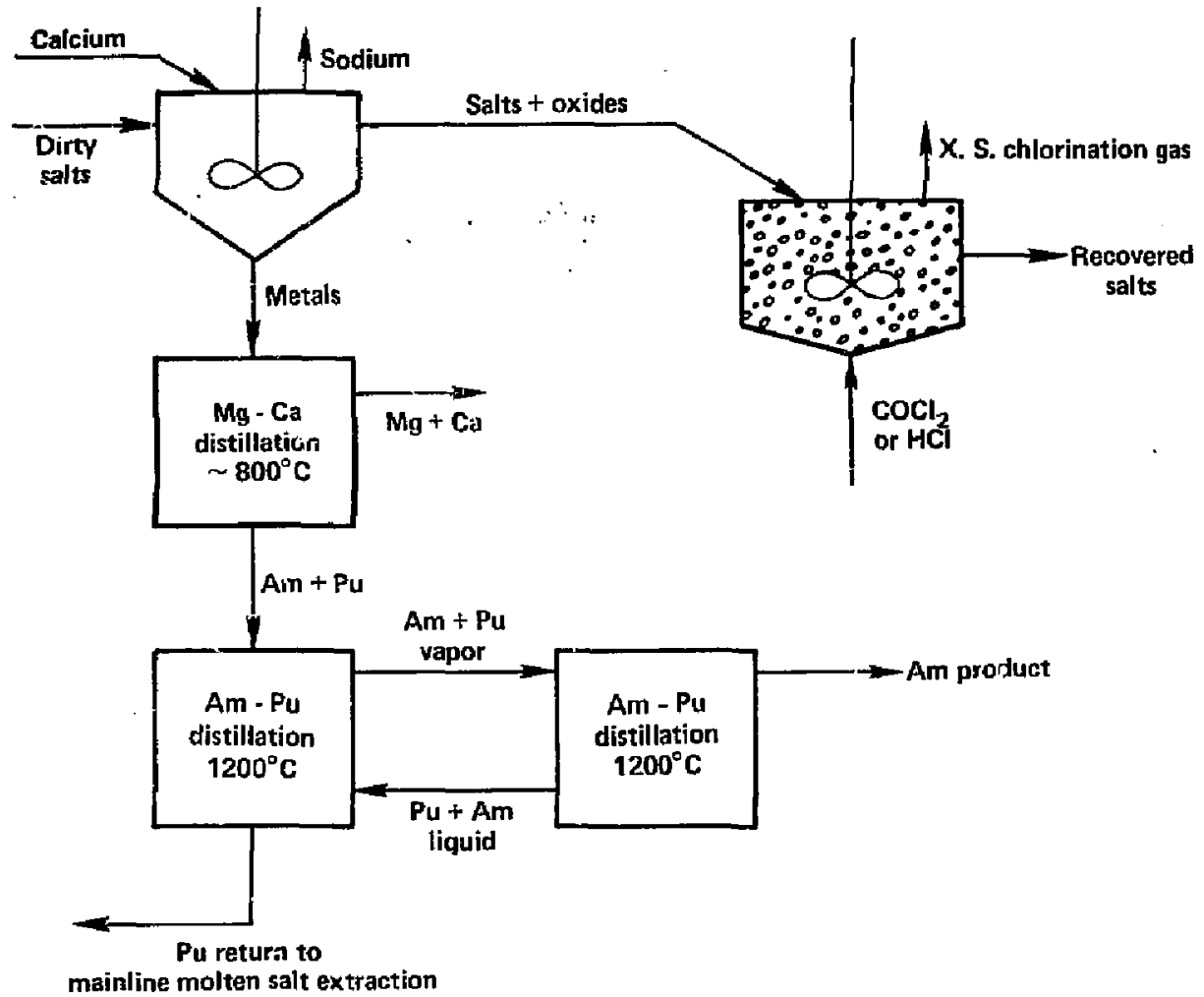

- FIG. 2. Salt regeneration. 
impuricies, largely Ga.* The heel represents 10-15\% of the Pu feed to the electrorefining tep.

The anode residues may be processed either by conventional aqueous means or pyrochemically. The pyroredox step described above has been proposed as a method of purification; this would allow return of essentially all of the Pu from the anode residues to the feed of the electrorefining step.

Large-scale application of pyroretox as an integral step in a process flow sheet will require additiosel development work. The current level of operation is a 2 -kg batch, and although the basic chemistry of the purification (oxidation with $\mathrm{ZnCl}_{2}$ followed by reduction with $\mathrm{Ca}$ ) has been thoroughly demonstrated, problems routinely occur in the disengagement of the $\mathrm{PuCl}_{3}$ phase from the 2.1 alloy. The problem is the formation of a third, "black salt" phase. In the laboratory, it is broken away from the salt in solid form and recycled. In production, it would be returned to rework, but in a se:icontinuous production process it could cause blurring of the phase boundary with resulting cantamination. Study of the salt/Zn/Pu system may provide a solution, as may clever equipment design that allows for recycle of an ir:determinate phase.

In production operation, the amount of impurities carried in this "black salt" is small. Impurities in feed can be decreased by a factor of 10 as the process now stands and are adequate for meeting present category $I$ metal specifications. Solving the "black salt" problem would produce ER quality setal.

The final steps of pyroredox are $\mathrm{Zn}$ recovery by evaporation and cleanup of the $\mathrm{CaCl}_{2}$ product. The $\mathrm{CaCl}_{2}$ cleanup is similar to that required followitg the molten salt extrection of Ar from $P u$ metal, and the same coments apply.

Processing of ZPPR Fuel

The second flow sheet, Fig. 3, concerns recovery of plutanium from zeco power plutonium reactor fuel. It is quite compact in comparioon with an equivalent aqueous process and, if side loops for salt reprocessing can be kept small in size, produces a minimal quantity of waste material.

* Delta Plutonium, a common allny, contains approximatcly $1 \%$ gallium and may constitut ; a substantial portion of the feed. 


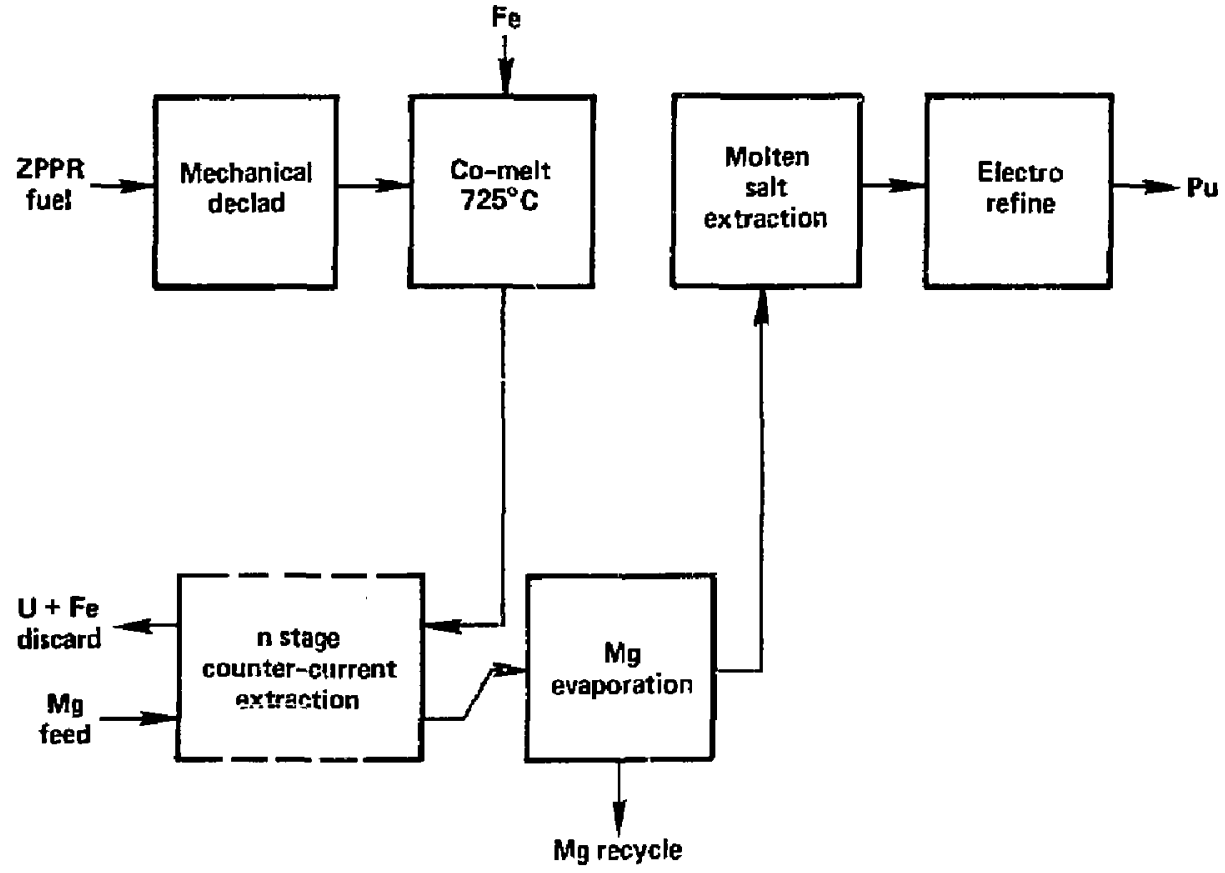

HIG. 3. ZPPR fuel processing--simplified process flow diagram. 
Simple mechanical decanning of the fuel is eavisioned as this fuel does not contain fission products.

The declad fuel, a U-Pu-Ho alloy, moves to the firgt pyrochemical process step, a metal-metal extraction as described previously.

The critical process step in this 2PPR fuel processing flow sheet is the partitioning of $P u$ from $U$. This is accomplished by co-melting the $U$ with Fe (ta lower the melting point, $725^{\circ} \mathrm{C}$ ) and contacting it with liquid $\mathrm{Mg}$. The $\mathrm{Pu}$ partitions to the $\mathrm{Mg}$ phase while the U-Fe does not. Four or more counter-current contact stages are needed to achievs the required degree of separation. The $\mathrm{Hg}$ is evaporated to recover Pu from the extractant. The U-Fe alloy could be processed by salt transport or pyroredox for $U$ recovery and Fe recycle, but the relatively low value of $D-3.8$ dictates that it is more economic to discard the $U$ fraction to waste.

Process equipment for this operation exists only conceptually, but could be designed with a major development effort. Research will be required to determine distribution coefficients more accurately than they are now known, and kinetic data are lacking that will be necessary for equipment design. An additional development requirement will be the determination of possible buildup of metals in the cover salt used to reduce Mg vapor losses.

The $\mathrm{Mg}-\mathrm{Pu}$ alloy is stripped of $\mathrm{Mg}$ in a vacuum evaporation step, actually a single-stage distillation.

The $\mathrm{Pu}$, together with any Am daughter, then moves forward to an Am extraction into molten salt and a final purification by electrorefining, exactly as it is processed in the first flow shoet for reclamation of Pu scrap material. These steps have already heen described and are rather well developed. The requirenerts for procesaing salts for recycle and treatacht of anode residues are the same as in the salt recycle case.

\section{Processing of RFP Salt Waates}

Salt waste from ${ }^{241}$ Am extraction from stockpile Pu is accumulating at $\mathrm{RFP}$; $\mathrm{Pu}$ (as $\mathrm{PuCl}_{3}$ ) is contained in this material, along with the $241_{\mathrm{Am}}$.

The material was originally $\mathrm{KCl}-\mathrm{NaCl}-\mathrm{MgCl}_{2}$, but it has degraded during extended storage in 55-gal drums and is partially hydrolyzed. The first proposed process step should be rechlorination (for example, with $\mathrm{Cl}_{2}$, HC1, or $\operatorname{cocl}_{2}$ (carbonyl chloride)) to provide starting material free of water and oxides. This step is we11-founded ehemically, but has not been tested for 
this salt mixture because 3sit-contacting equipment, Even at pilot scale, that would be suitable for this operation does not now exist. Some technology developmeat will be required to implement tris step.

Rechlorinated salts fron the first step would proceed to a ca reduction step, whici is the same as the reduction shown for extraction balt recycle in Fig. 2. The reduction product is a Ca-Mg-Pu-An alloy that is perticioned to $\mathrm{Ca}-\mathrm{Mg}$ and $\mathrm{Pu}-\mathrm{Am}$ by vacuum evaporation at $2800^{\circ} \mathrm{C}$.

Because this particular application of pyrochemistry deals with a manageable amount of existing waste and can recover pure $\mathrm{Pu}$, the economic benefics are very great. The experience gained in addressing a problem even of this limited size would be of great value in demonstrating the potential of pyrocharistry in other, larger scale applicacions.

\section{Process Sumary - Development Requirements}

Pyrochemical methods have three benefits: large separation factors in some cases, high density and concentration of in-.rocess materials, and radiation resistance of salts and metals. There are also three disadvantages: high temperatures, exotic materials of construction, and in some cases excessively dilute in-process streams. Each particular application muat be considered separately.

The three near-term applications we have discussed for pyrochemical processing of unirradiated nuclear materiais demonstrate the potential of pyrochemistry as a process option. The major factor inhibiting its use for other than Pu processing is lack of experience in its large-scale application in shielded, remote facilities.

While the basic chemistry of each of the processes described in this . report is known and has been applied at labocatory or stall product aon scale, the descriptions of the process steps and flow sheets have pointed out four areas where basic research and development work is necessary:

1. Construction materials need extensive improvement.

2. Frocess equipment for remote maintenance pyrochemistry must be disveloped.

3. Instrumentation for process control and for optimum reagent use must be developed.

4. The available data base will need to be expanded by regearch in three areas: 
a. Digtribution coefficients for gelt-metel, metal-metal, and ternary, etc., systems

b. Tapor liquid equilibrium data for metal distillationg

c. Kinetics of reactions and interphase transport data for salt-metal, metal-metal, gas-salt, etc., systems.

None of the requirements for development presents an overwhelming problem, and in fact some pyroprosessing at ton/year rates has been used aince 1967. What is necessary is that one or more of the most advantageous pyrochemical applications actually be designed and built as an integrated process, so that a foundation of experience can be laid that will eventually place pyrochenistry in a more competitive position with respect to traditional techniques. 


\section{EVALJATION OF PYROPROCESSTNG TECHNOLOGY}

\section{Introduction}

The principles of pyrometallurgical treatment of ores remain unchanged from early historic times, although refinements in operating methods and changes in scale have been achieved. The applications considered for materials of interest here pose six difficulties over more conventional ore refining.

1. Plutonium is extremely valuable, reactive, and toxic.

2. Nuclear criticality limits quantities of materials handled at one time. (The absence of water is highly advantageous.)

3. The chemical reactivity of thege materials requires inert atmosphere operetions.

4. Separations from quite similar chemicai elements are often required.

5. Separations from a large number of chemical elements simultaneously may be required.

6. Final products of very high purity are usually desired.

Extensions of the existing operations to include all steps potentially applicable to plutonium resycle and production will not require major changes in the nature of the operations. However, extensions to large-scale shielded operations necessary for spent nuclear fuel reprocessing with uranium and pluronium separation and decontamination would necesaitate major technology development. Some issues related to spent-fuel processing will be discussed later.

The nature of Pu production processes discourages changes from the current batch concept. The procesa steps are each carried to completion; no continuous operations are involved. Scale-up to large or continuous processes offers no major advantage because of eriticality considerations, the high dengity of liquid plutonium, and the great differences in densicy berween molten salts and molten plutonium. The high densities imply that continuous operations with flow between steps must involve small streams or very heavy weights; mass limits imposed by criticality constraints require that plutonium inventories remain swal1: therefore, flow systems would be restricted to quite small volumes. There may be no ret advantages in truly con $\dot{i}$ uous gperations 
for these procesges. However, continuous operation without the need for long heat-up and cool-down times could lead to large increases in throughput while still retaining the bateh process and inventory control aspects of the current procedures.

Electrorefining is inherently a batch process, and a ceil, once charged, runs theoretically at no net througiput. The principles uf electrorefining require that a batck heel must be removed with the impurities. To avoid contaminant carryover, a significant quantity of plutonium must be left in the anode heel co be reworked. Replacement of the electrorefining process with pyroredox (when developed) will have the potential of semicontinuous operation. At present, the pyroredox option consists of two steps that require substantial additional chemical development to perfect the process. Initial experience at Rocky Flats Plant ${ }^{3}$ was limited by poorly engineered and installed equipment. Further developinent must be carried out on the chemistry of this system, and questions gtill remain regarding the required purity of the process salts and the fate of minor constituents in recycle streams. All of these issues must be resolved before attempts to operate in a senicontinuous mode can be undertaken.

The optimum pyroprocess may vary according to the application. Capacity requirements appear to be adequate in the batch mode for scrap and weapons plutonium rework if the complete system is in place. Support for the hanford plant plutonium isotope separation may reqrire semicontinuous operations to handle process internal recycle streams. This application may introduce bulk impurities into recycle streams that have not been considered in the chemistry process research.

Operation of the petal processing line at LLNL will initially produce byproduct streams for which no recycle capability is currently available. Plans have been laid out by LLNL plutonium technology scientists to complete the chemistry experiments necessary to develop these processes. Conceptual processes do exiet, as described above in Chapter III. These new processes czeate new thaterial problems and new off-gas ileanup problems that have not yet been evaluated. Line-generated wastes will be treated off-site. That work is directly supportive of the equivalent needs of the RFP processing and would be appiicable to a plant-scale isotope separation process.

Comparison with the chemistry research and development that was done for the purex process flow sheet is of interest. It has been estimated that more 
than 1000 man-years were expended to measure all of the checaical parameters for all of the elements of importance to that application. More nearly 100 man-years have been expended on the detailed cheraistry of pyroprocessing. It is estimated that another 50 man-years will be required to sort through the chemistry issues that revolve atound the metal processing line and Rocky Flats Plant applications. Because of the lack of pyrochemical data, it is impossible to do a direct comparison of pyro veraus aqueous processes for all applications. It is also very clear that once one is working with metallic plutonium or plutonium oxide, there is a major advantage ir. staying in the nonaqueous system, if at all possible. A comparative analysis done for RFP applications shows $a n$ advantage in going to a nonaqueous process even if it is racessary to expend 50-75 man-year developsent costs up front. ${ }^{2}$ The process chat is eventually targeted retains an approximate 10 percent aqueous stream capacity for miscellaneous support operations. That 10 pereent, on a fraction of plutonium inventory throughput basis, represents equivalent floor space requirements because of the dilute nature of the waste, scrap, or byproduct streams that are reconcentrated by aqueous routes. ${ }^{4}$

This requirement for aqueous processes to support the mainline pyroprocess approximately doubles the minimu floor space (increasing the direct capital cost accordingly). Analysis of the conceptual flow sheets for side-stream rework of a complete pyro line indicates at least a doubling of the number of process steps; in addition, there will be an increase of a few percent in the load to the mainstream processes. These conceptual processes for the side streams produce much more waste per $\mathrm{kg}$ of plutonium throughput than does the main process; however, the net waste produced for the totaI process is increased only on the order of $5 \%$ by these side streans.

Processes such as purex also generate side-stream waste, and comparisons with pyrochemistry require an equal basis. The important point is that side streams and support procesges are often neglected, particularly in conceptual prosesses, which tends to make conventional, well-understood techniques appear much mize complex than less well-understood competitors. We have attempted to remove this bias in cur comparisons.

\section{Spent Nuclear Reactor Fuel Processing}

Commercial scale reprocessing of spent fuel has been conducted worldwide. Conceptual pyroptocesses have been proposed for recovery of uranium and plutonium from spent nuclear reactor fuel, but these have not been defined in 
the detail required for developmen: of plant designs and flow sheets. 5 We can only escimate such factors as chemical consumption, the mass transported in process, heating requirements, side stream rework, and amounts of waste produced.

Figure 4 presents a block diagran of the major operations in a spent nuclear fusl processing plant. Figure 5 provides a schematic flow sheet ícr a pyro separation process for irradiated fuels. Figure 6 is a comparable sketch of the purex separation process.

From these simple sketches of the nuclear reprocessing plant, we can develop a clear impression of the fraction of the facility that will be replaced or significantly altered by a nonaqueous process. Specisl accomodations in the conventional parts of the plant to couple pyrochemical operations to the nonaqueous support systems will sharply decrease the apparent advantages of pyro's reduced size and number of steps.

We will review the operations show in Fig. 4 and compare these operations in the aqueous plants and in the conceptual pyro plant. Reference numbers refer to major blocks outlined an Fig. 4.

1. Fuel Re eiving and Storage

These operations are highly dependent on the specific fuel design and its operating history, but are independent of what is to be done with the fuel in processing. Fuel can be processed in nonaqueous systems that are cooled for shorter times than is acceptable for aqueous/organic systems. Therefore, a nonaqueous system needs less storage for fuel cooling in the total cycle; the plant requires only onsite feed inventu-y quantities. If cooling times are too short, a new protlem arises with contaiment of short-lived fission products; that is not a consideration for the backlog of unprocessed fuel existing today.

2. Mechanica1 Headend

The mechanical headend cell must allow for movement of the fuel from storage, through cleaning, to the mechaaicel preparation room. As much surplus hardware as possible should be removed from any fuel type. This removed hardware requires further handling for waste disposal. That disposal problem is simpler from the headend cell in all cases than is providing for separation and disposal at a later stage in the process. Chop-1each as now used for light water reactor (LWR) type fuels requires a large high-power shear plus special baskets to xemove the hulls from the dissolver and packaging for disposal. Conceptual aqueous 


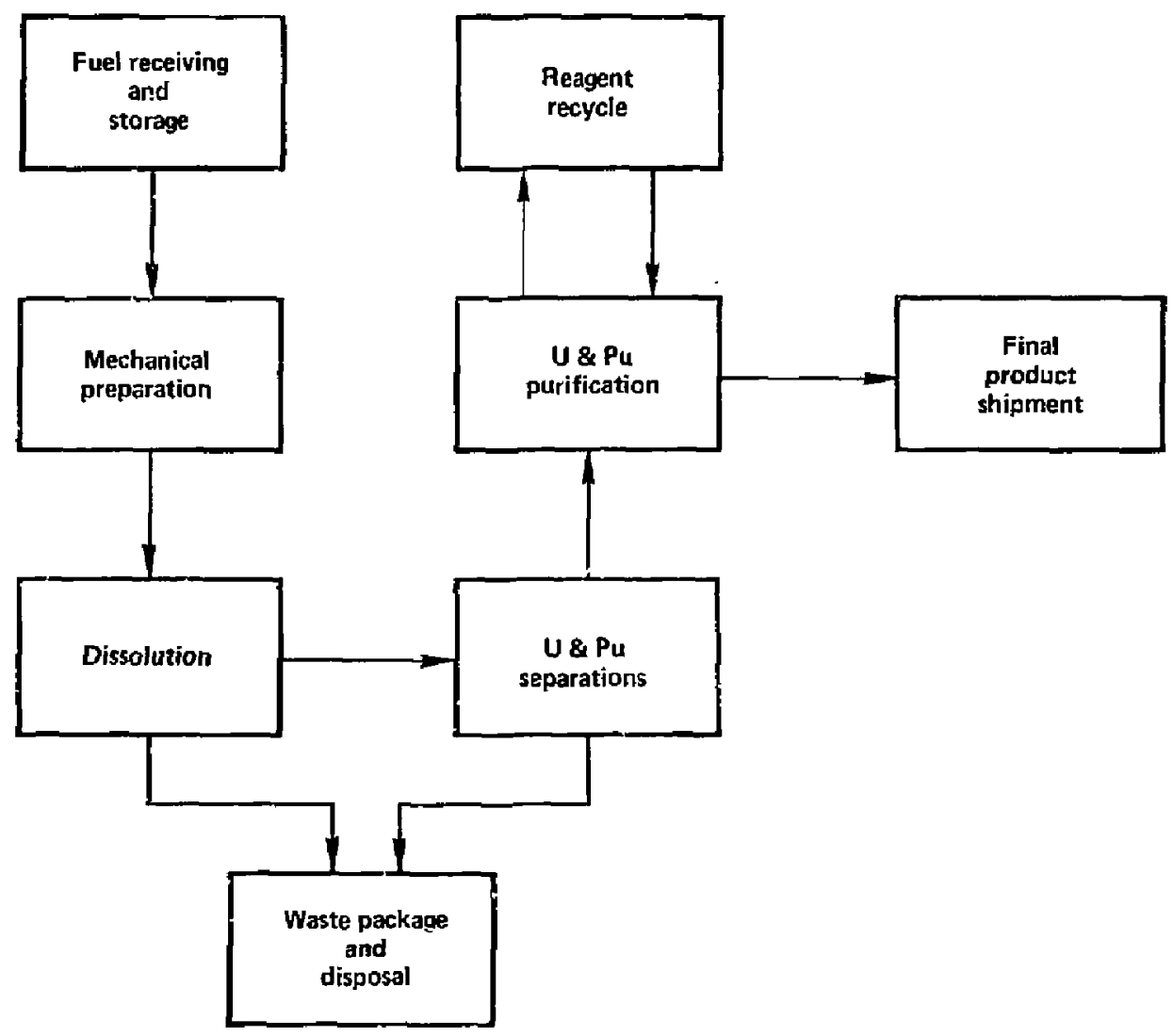

FIG. 4. Block diagram of operations. 


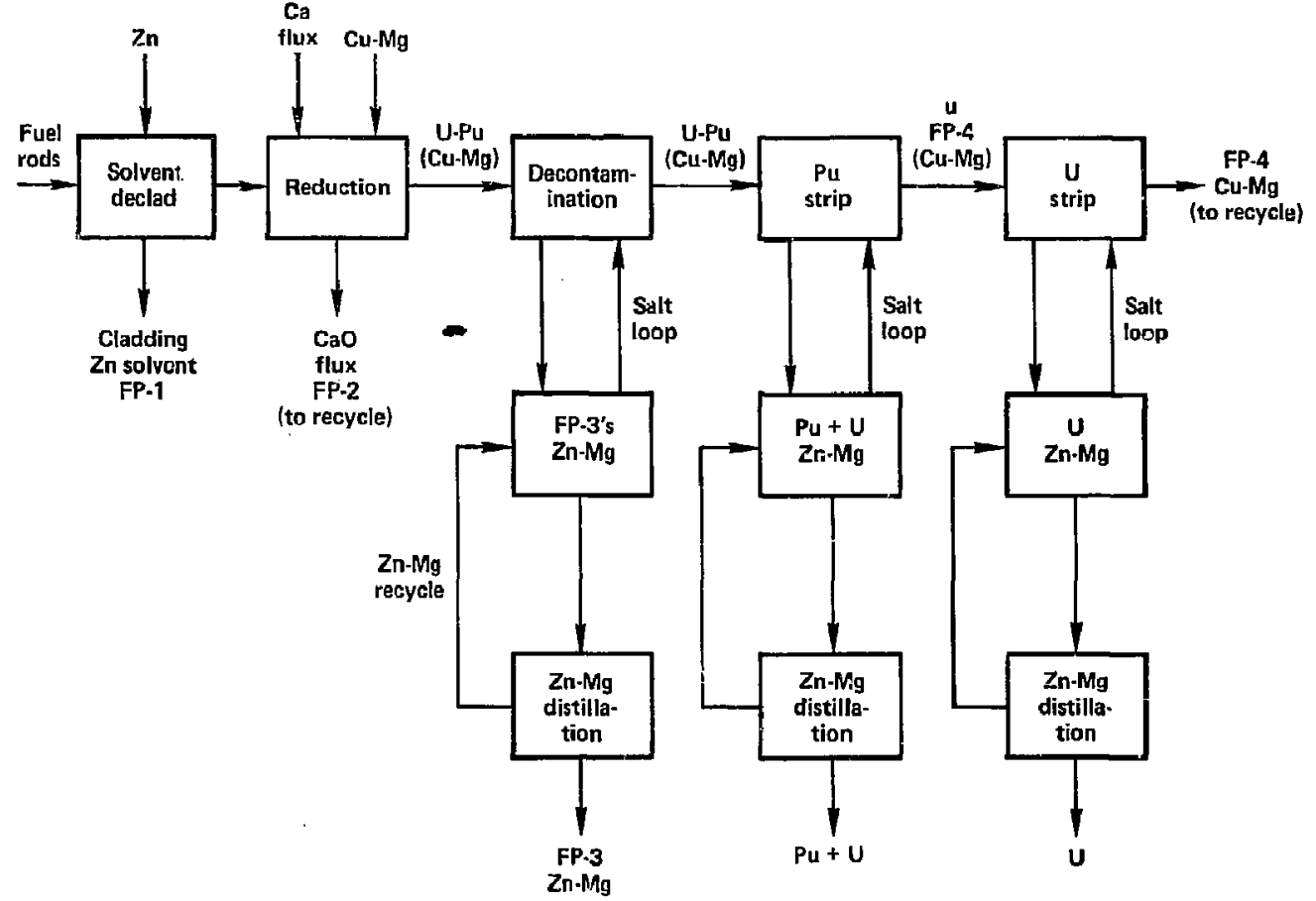

FIG. 5. Conceptual pyroproces s for $\mathrm{UO}_{2}-\mathrm{PuO} 2$ fuel. 


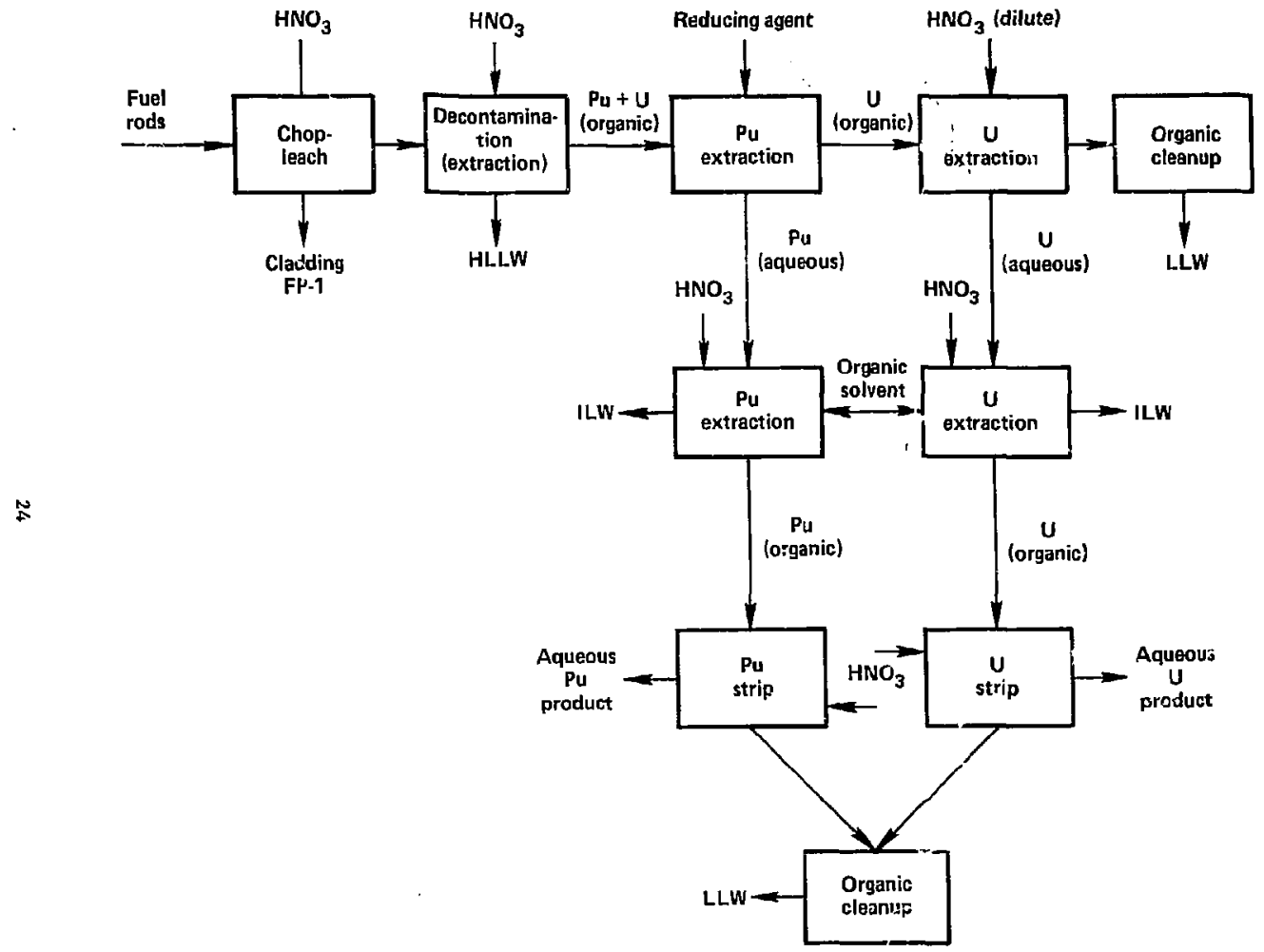

FIG. 6, Conceptual aqueoug (Purex) process for $\mathrm{PuO}_{2}-\mathrm{UO}_{2}$ fuel. 
flow sheeta foi tiquid metal fast breeder reactor (LMFBR) cype fuels also generally acsume chop-leach operations with cladding hulls being removed from the dissolver. These combined operations, excess hariware removi.1, shearing of whole fuel bundles, and spent-hull removal dictate the size of the headend mechanical cell.

For the high-temperature gas-cooled rezctor (HTGR) graphite, bandling and size reduction are necessary to prepare the fuel for burning. No fuel element materials are diver'sed to waste disposal at this first mechanical step.

Kechanical removal of excess hardware should be accomplished before the dissolution step for both procasses. If the proposed zinc dissolution decladding process works satisfactorily for LWR and LMFBR fuels, the space required for shearing sould be eliminated from the pyro plant design. Removal of the cladding sponge from $z$ inc solvent for the pyroprocess will be equivalent to hull handling from the aqueous leaching. Following removal fiom the dissolver, the sponge or hulls must be compacted, packaged, and stored for shipment to dispesal. These operations are essentially equivalent for the two processes. The net difference in mechanical operations is the absence of the shear in th.: conceptual pyroprocess. That shear is the most difficult meshanical operation in the purex process.

3. Decladding and Dissolution

Shearting of whole-fiel bundes is followed by dissolaticn of the fuel meat in aqueous nitric acid. This aqueou streas is transferred to accoutability and feed adjust tanks and then fed to a series of extraction steps for separation of the uraniam and plutonium and the decontamination of both of these from fission products.

The dec?adding and preparation for dissolution steps for the HTGR involves burning of the crushed material in at least two separate stages. Silicon carbide hulls on the fuel pellets are then cracked or crushed, and this product is finally fed to an acjd dissoiver. Beyond this stage, separtion and purification of the thorium and uranium are gimilar to the aqueous process for plutanium and uranium. Therefore, we will not separately discuss the HTGR process further.

In the conceptual pyroprocess for LWR/LMFBR fuels, the decladding is a disintegration of the metal clad by molten zine or other suitable material as described above. 
This melt is separated from the ( $\mathrm{UO}_{2}, \mathrm{PuO}_{2}$, fission products) fuel mear, and the zinc metal is distilled away from the cladding. The residual metal eladding sponge is then compacted for storage. The solid oxide fuel is reduced by calcium with the uranium and plutonium being taken up in a copper-magnesium (or other) alloy. Some fission products are separated into the salt at this stage. As in the agueous process, provision must be made for the required safeguards accountability measurement at this stage. Following the calcium reduction step, the U, $\mathrm{Pu}$, and fission products are separated and decontaminated chrough a series of steps similar to those require 1 for the aqueous system.

The chemistry, the operating conditions, and the process hardware are quite different for the two approaches, but when we look more closely at the steps in the two processes, we see a great similurity. This should not be surprising. There are four requirements:

$$
\begin{aligned}
& \text { a. Separate the cladding from the fuel } \\
& \text { b. Separate the } U \text { and } P u \text { from fission products } \\
& \text { c. Separate the } \mathrm{Pu} \text { from the uranium } \\
& \text { d. Purify the } \mathrm{U} \text { and } \mathrm{Pu} \text { as required. }
\end{aligned}
$$

In the purex process, shown in Fig. 6, the uranium and plutonium are separated from most of the fission products in the first-cycle extraction colum; the Pu and $U$ are then separated in the first-cycle separation colum. The uranium and plutonium are then separately put through one additional cleanup cycle to further remove fission products.

The operations for the pyroprocess are similar following the decladding; the dissolved fuel is put through a process in which plutonium is separated from uranium by extraction into a salt and back extraction to another alloy. The uranium then goes through an extraction cycle. Additional cycles will be required for adequate decontamination of both the $\mathrm{Pu}$ and $\mathrm{U}$; much af the research and development manpower that was expended on the purex process (as mentioned earlier) was spent on developing multistage contacting equipment to enhance separations in each cycle. This same area should be a major focus of pyroprocess development work.

The two processes again are seen to requize similar procesges and foughly equivalent nuxbers of steps. In terms of difficulty, the aqueous system has advantagee because the low temperature and conventional equipment made from readily worked stainless steel give a very big "familiarity" edge to the 
aqueous system. When the chesistry is completely known and acceptable materials, process equipment, and inatrument and control systems are fully identified, the pyroprocess will still be at a disadvantage because of the high tenperatures and inert atmospheres required.

\section{Off-Gas Cleaning}

off-gas cleaning from fuel processing is required to retain fission products $\mathrm{Kr}$ and $\mathrm{I}$ and to prevent other volatilized fission products (e.g., Cs and $R u$ ) from escaping to the enviranment. The inert atmosphere required for the pyroprocess should work very well in off-gas cleaning systems; capture of ${ }^{3} \mathrm{H}, \mathrm{Kr}$, and I should be readily accomplished. The chemical load transported to the off gas because of the high temperatures remaing unspecified.

The syrtems for cleaning off gas from the aqueous systems have been designed on the basis of pilot plant tests. The required retention of krypton, tritiun, and carbon-14 for HTGR remain unproven.

\section{Final Product}

The product will be either a metal or an oxide depending on the process and the use intended for the product. Because of the high capital investinent needed for plutonium or uranium nitrate conversion to oxide, serious consideration should be given to the intended application. The pyroprocesses are currently designed to produce plutoniun metal as the final step in purification; conversion of the purified metal to pure oxide would be requixed for return to conventional LWR fueis. These are process and application specific. This part of the plant process is not a major part of the total plant costs.

\section{Wastee Production}

Wastes produced by aqueous and nonaqueous processes are in different chemicâl form, but are otherwise similar in content, as shown in the flow sheet in Fig. 4. In both aqueoug and nonaqueous systems, the major chemical contents of the process streams are proposed for recycle. Ir. the aqueous streams, the major component is water; the eventual fate of ail of this water will be uncontrolled release. Nitric acid is recoverable; most other waste chemicals are eventually incorporated into one of the wate 
fractions: high-level waste (HLW), intermediate-level waste (ILW), or low-level waste (LLW). These wastes will eventually be converted to a stabilized form suitable for disposal according to the applicable criteria.

The tocal wastes that would be produced per ton of fuel from an optimized pyroprocess have not beed established. The flow sheet shown in Fiz. 5 and used for discussion might initially be operated by discarding or storing all salts and alloys carrying products. An actual plant operacion would expect to recycle much of chese atreams with the minimum possible discarded as carriets for the fission products. The total salts or alloys discarded will be transuranic or higher level wastes. No general release will be possible, in contrast to the case with vater from the aqueous system. It is difficult to imagine that the total final form HL wates produced by pyroprocessing would be less than the currently projected $<80 \% / M T U$ final glass waste form for the LWR-purex process.

\section{Intercycle or Interprocess Storage Requirements}

Aqueous plants rely on intercycle storage capacity for the sccumulation of the product from one process, appropriate process chemical adjustments, ant feed to the next process at an appropriate rate. Because of lack of detail for the pyrochemical-based flow sheet, an evaluation of the intercycle storage and pracess adjust steps cannot be made. From the information available $n$ feed compositions and concentrations, the atreams can be estimated to be fairly large for managing the total stream from LWR fuel dissolution. Uranium solubility in these alloy/salt systems appears to be a limiting factor in good flow sheet development.

Current pyro applications are for small batches; the interprocess storage requirement is only a piece-count problem. In a full-scale, remote, radioactive application, considerable thougt must be given to product and byproduct handing from each otage. Because these materials solidify at well above normal working temperatures, allowance must be made for keeping then hot and/or for $s$ toring them in rehentable tanks. Such equiprent requires increased complexity and maintenance. Adequate space must be provided for operations and for remote recovery from failed equipment and abnotmal operations.

The lack of detail for the posible pyrochemiatry-based flow sheets precludes the evaluation of mismutches between process steps and the impact of 
process upsets. Allowance must be made beth for chemical rework of process upsets and for the mechanical maintenance problems referred to above. Decontamination and final cleanup of equipment for maintenauce will be done at least in part with aqueous solutions: Contaminated scrap and scme

Iine-generated wastes will be leached, if appropriate, and recycled as is now done at the LANL scrap recovery. ${ }^{4}$

The total intercycle storage (tankage) and waste volumes have not been eatimated with any accuracy because of lack of flow sheet chemistry detail. It can be seen from the generalized discussion above that many of the chemical side stream rework problems are similar to the aqueous plant problems.

1. Low-level and trace residual chemical materials often are best removed with aqueous cleaning.

2. Any of the pyrochemical operations that require movernent of process equipment wili require extra room for manipulators and connect/disconnect jigs.

3. All high-maintenance equipment will need to be accessed for remote replacement.

4. Feedthroughs for electrical equipwent, rotating feedthroughs for stirrers and pump rotors, and mechanically operating valves or diverters will require access for maintenance.

5. Major desigo and operational issues remain open before the final layout and operational evaluation can be completed for the pyrochemical processes.

It is apparent from the above brief evaluation that a totally nonaqueous facility for spent-fuel reprocessing is not possible at present without a major development effort. Aqueous systems for support of the main process probably will always be required. The mechanical manipulations and expected high maintenance of the pyrochemical process equipment will increase the in-cell space requirements far beyond those apparently indicated by the high density of the process streams.

\section{Kelacive Stream Volcmes and Neights}

Although the process streams are high density and plutonium is very soluble in some of the proposed salts and alloys, uranium is not nearly so soluble in the alloys and salts identified. Dissolution of the equivalent of 
$1000 \mathrm{~kg}$ of U metal requires about $9000 \mathrm{~kg}$ ( 1500 liter) of Cu-Mg alloy in the pyrochemical process applied to pressurized water reactor (PWR)/boiling water reactor (BWR) fuels; the same procest requires $6000 \mathrm{~kg}$ ( +6000 liter) of 3H nitric acid leachant in conventional processes. While the aqueous liquid occupies at least four times the voiume of the alloy solution, it can be handled at room temperature while the alloy must be handled at $700^{\circ} \mathrm{C}$. While the entire $1000 \mathrm{~kg}$ of $\mathrm{U}$ may not be in solution at any one time, the relative weights and volumes still move between process steps. Further, it is not necessary that the entire toil of U-Pu fuel be dissolved simultaneously in the aqueous process. What is required in both cases is that the minimus unit that can be identified be dissolved and measured for safeguards accountability reasons. That unit can be a single fuel element in either the aqueous or the pyroprocess. Each will require that the minirum batch be homogenized adeģuately to provide a representative sample for uranium and plutonium analyses. The dissolver product, therefore, shows no advantage for pyrochemistry.

The dissolver itself is another poiat for comparison. In aqueous processing, it rejects cladding hulls and volatile fission products/gases. In the pyrochemical method, the dissolver rejects these items, plus almost $12,000 \mathrm{~kg}$ of $\mathrm{CaO} / \mathrm{CaCl}_{2} / \mathrm{CaF}$ flux contaminated with several $\mathrm{kg}$ of fission products. The reprocessing of the waste flux and $\mathrm{CaO}$ is a large task, but must be accomplished because this waste would otherwise occupy essentially the same volume as the entire aqueous dissolver product.

During the decontamination and separation processes, pyrochemistry enjoys a volume reduction, particularly over $U$ in organic phases, where $1000 \mathrm{~kg}$ of metal require about 16,000 liter of aqueous solvent, while the minimur alloy volume ig 4000 liter. The total mass of in-process material is, however, about equal, and again the pyrochemical sygtem must be maintained at $700^{\circ} \mathrm{C}$. Eroducts are weight equivalent: nitrate solutions, about 3500 liter per MT for aqueous, $\mathrm{Zn}$ solutions/intermetallics, about $3500 \mathrm{~kg}$ or 500 liter for pycochemistry; the volume reduction is a factor of 7 .

Wastes are difficult to evaluate: with total internal recycle and waste volumes reduced by evaporation/combustion/electro-winning from solution, net waste should be equivalent for either process. Any comparison would have to be based on actual purex va conceptual pyro, and would have little meaning without far greater detait than is now available for pyroprocessing. 
1. D. C. Christensen and L. J. Mullins, Pregent Statug of Plutonium Metal Production and Purification at Los Alamog--1982. Los Alamos National Laboratory, Los Alamas, NM, LA-9674-MS (June 1983).

2. R, L. Sandvig, A Comparison of Plutonium Recovery by Aqueous and Pyrochemical Methoda. Rockwell International, Golden, Co, CRD 79-014 (Japuary 18, 1979).

3. J. Knighton, unpublished report.

4. A. E. Nixon, B. J. McKerley, and E. L. Chriatensen, "Plitonium Scrap Processing at the Los Alamos Scientific Laboratory." Submitted to the 24th National Symposium for Chemical Technicians/179th Nationsl Meeting of the American Chemical Society, March 24 and 25, 1980, Houston, Texas.

5. J. B. Knighton, "Pyrochemical Erocessing of LWR and LMFBR Fuels by the Salt Transport Kethod," Akademische Verlagsgesellschaft, Wiegbaden, 1978.

NMS/bw 
The purpose of this appendix is to provide a more detailed description of the chemical processes involved in process steps than was given in the body of the text.

It draws heavily on the published work of M. S. Coops and J. B. Knighton, which has been included in edited form with their consent.

A bibliography of recent survey articles on pyrochemical techniques applied to nuclear materials can be used by the reader to obtain further information.

\section{Reduction of Rlutonium Oxide to Metal}

All actinide metals are pyropäoric, and it is common practice to burn metallic scrap to oxide as a safety precaution. Plutonium is cypically stored as $\mathrm{PuO}_{2}$ and must be chemically reduced to metal prior to component manufacture. This has craditionally been done by precipitating $\mathrm{Pu}_{2}\left(\mathrm{C}_{2} \mathrm{O}_{4}\right)_{3}, \mathrm{Pu}\left(\mathrm{O}_{2}\right)_{2}, \mathrm{Pu}(\mathrm{OH})_{3}$, or $\mathrm{PuF}_{3}$ from solution and converting it to $\mathrm{PuF}_{4}$ for bonb reduction to meta1. This method is now being replaced by direct reduction techniques.

The first successful reduction of $\mathrm{PuO}_{2}$ to metal with calcium was reported in 1958. The procesg was carried out in two stages: an initial thermit reaction between $\mathrm{PuO}_{2}$ and $\mathrm{Ca}$, followed by a leaching step with $\mathrm{CaCl}_{2}$ to dissolve the CaO reaction product and any unreacted Ca. The fluid flux permitted finely divided plutonium to coalesce into a pool of metal. Rotation of the inclined reaction vessel was used to promote slag dissolution and metal consolidation. The original process has since been significantly i. ?roved by workers at several DOE sites.

The DOR pracess now used for production work utilizes a $\mathrm{CaCl}_{2}$ (or $\mathrm{CaCl}_{2}-\mathrm{CaF}_{2}$ ) flux both to dissolve the CaO reaction product at the reaction site and to provide a fresh supply of $\mathrm{Ca}$ reductant to keep the reaction going. This process exploits the solubility of $\mathrm{Ca}$ and $\mathrm{CaO}^{\mathrm{in}} \mathrm{CaCl}_{2}$ while utilizing the insolubiliz; of plutonium metal in the $\mathrm{Ca}_{-} \mathrm{CaO}-\mathrm{CaCl}_{2}$ reaction flux to permit metal consolidation. Vigorous stirting is ued to keep the reactants in intimate contact so that the reaction is driven :o completion. Recent development work at LANL has increased the batch size to one kilogram of oxide feed. It appears that the liritation on DOR batch size will be from sriticality safety constraints. 
This direct oxide reduction process is replacing fluoride reduction as it eliminates neutron exposure to operating perconnel (alpha particles from piutonium deray have sufficient energy to eject neutrong from fluorine by the a,, reaction) and eliminates reduction residues that require subsequent treatmeat for Pu recovery.

In the LANL application, the reaction is carried out under an inert atmosphere in an open crucible at approximately $830^{\circ} \mathrm{C}$. Vitrified magnesium oxide ceramic is commonly used as a container material, but tungsten and tantalum can also be used. If the latter are used, $\mathrm{CsF}_{2}$ is added to lower the temperature needed to 1 iquefy the flux, thereby decreasing the corrosion of the crucible and subsequent contamination of the metal product. Intense stirring is required to keep all of the reactanto in contact as the very dense $\mathrm{PuO}_{2}$ sinks and $\mathrm{Ga}$ metal floaks in the meit. The reaction is exothermic, and a temperature rise occurs after initiation. The overall chemical reaction is:

$$
\begin{gathered}
\mathrm{PuO}_{2}+2 \mathrm{Ca} \rightarrow \mathrm{Pu}+2 \mathrm{CaO} \\
\Delta \mathrm{G}=-44.27 \mathrm{kCal} \text { at } 1000 \mathrm{~K}
\end{gathered}
$$

The rechanism for the reaction is not fully understood at present, but is believed to take place in several steps. Several of the possible reaction. species and their free energy of formation are listed below:

Compound
$\mathrm{PuO}_{2}$
$\mathrm{a}-\mathrm{Pu}_{2} \mathrm{O}_{3}$
$\mathrm{~B}-\mathrm{Pu}_{2} \mathrm{O}_{3}$
$\mathrm{PuO}$
$\mathrm{CaO}$

One possible reaction mechanisu is

KCa1/ulole
-210.130
-367.696
-343.542
-113.057
-127.200

$\Delta G$ a $1000 \mathrm{X}$

RCal/gr-ATM oxygen

-1. 5.065

$-122.565$

$-114.647$

$-113.057$

$-127.200$

$$
\begin{array}{ll}
\frac{\text { Reaction }}{2 \mathrm{PuO}_{2}+\mathrm{Ca} \rightarrow \mathrm{BPu}_{2} \mathrm{O}_{3}}+\mathrm{CaO} & \frac{\Delta G \mathrm{G} 1000 \mathrm{~K}}{-50.882 \mathrm{KCal}} \\
\mathrm{BPu}_{2} \mathrm{O}_{3}+3 \mathrm{Ca}+2 \mathrm{Pu}+3 \mathrm{CaO} & -37.658 \mathrm{kCal}
\end{array}
$$


It is also feasible to assume the following mechanism:

$\begin{array}{ll}\text { Reaction } & \frac{\Delta \mathrm{G} 1000 \mathrm{~K}}{\mathrm{PuO}+\mathrm{CaO}} \\ \mathrm{PuO}_{2}+\mathrm{Ca}+\mathrm{PuO}+127 \mathrm{KCal} \\ \mathrm{PuO}+\mathrm{PuO}_{2}+\mathrm{Pu}_{2} \mathrm{O}_{3} & -20.755 \mathrm{kCal} \\ \mathrm{BPu}_{2} \mathrm{O}_{3}+\mathrm{Ga}+2 \mathrm{PuO}+\mathrm{CaO} & -9.372 \mathrm{kCal} \\ 3 \mathrm{PuO}+\mathrm{Pu}+\mathrm{Bu}_{2} \mathrm{O}_{3} & -4.771 \mathrm{kCal} \\ \mathrm{PuO}+\mathrm{Ca}+\mathrm{Pu}+\mathrm{CaO} & -14.143 \mathrm{kCal} \\ 3 \mathrm{PuO}_{2}+\mathrm{Pu}+2 \mathrm{BPu}_{2} \mathrm{O}_{3} & -57.497 \mathrm{KCal}\end{array}$

An additional back reaction can occur between $\mathrm{BPu}_{2} \mathrm{O}_{3}$ and $\mathrm{PuO}_{2}$ to for $\mathrm{aPu}_{2} \mathrm{O}_{3}$. Conditions leading to the formation of $\mathrm{aPu}_{2} \mathrm{O}_{3}$ are to $\mathrm{t}$ ? avoided as the reaction between a single atom of $\mathrm{Ca}$ and $\mathrm{aPu}_{2} \mathrm{O}_{3}$ is not thermodynamicaliy favorable:

$$
\begin{array}{lr}
\mathrm{aPu}_{2} \mathrm{O}_{3}+\mathrm{Ca}+2 \mathrm{PuO}+\mathrm{CaO} & +14.382 \mathrm{kCal} \\
\mathrm{aPu}_{2} \mathrm{O}_{3}+2 \mathrm{Ca}+\mathrm{Pu}+\mathrm{CaO} & +0.239 \mathrm{kCal} \\
\mathrm{aPu}_{2} \mathrm{O}_{3}+3 \mathrm{Ca}+2 \mathrm{Pu}+2 \mathrm{aaO} & -13.904 \mathrm{kCal}
\end{array}
$$

Although the exact chemical mechanism for the direct oxide reduction reaction has not yet been fully tharacterized, it has been well establishec that the reaction goes to completion when excess calcium is present, sufficient $\mathrm{CaCl}_{2}$ is available to dissolve ths CaO produced, and adequate stirring is used. As calcium metal is soluble to about 1 wto in $\mathrm{CaCl}_{2}$ at $835^{\circ} \mathrm{C}$, excess $\mathrm{Ca}$ ensures that the reaction is driven to completion by mass-action effects.

The $\mathrm{CaCl}_{2}-\mathrm{rich}$ end of the $\mathrm{CaO}_{\mathrm{CaCl}} \mathrm{Ca}_{2}$ phase diagram has been worked out and is show in Fig. A-1. The phase diagrams indicate that CaO is soluble to 18.5 mole $\%$ in $\mathrm{CaCl}_{2}$ at $835^{\circ} \mathrm{C}$, but if the loading of $\mathrm{CaO}$ rises much above 14 mole $\%$ the increased viscosity of the melt retards consolidation of the droplets of plutonium into a single pool. The 700-gr $\mathrm{PuO}_{2}$ reduction process at LAWL uged 50 mole \% excess calcium reductant and a CaO loading in $\mathrm{CaCl}_{2}$ of about 14 mole $\%$, to give product yields in excess of $99.5 \%$. After the melt is allowed to cool, an ingot of olutonium metal can be readily cleaved from the solidified flux. The salt phase contains negligible uareacted $\mathrm{PuO}_{2}$. 


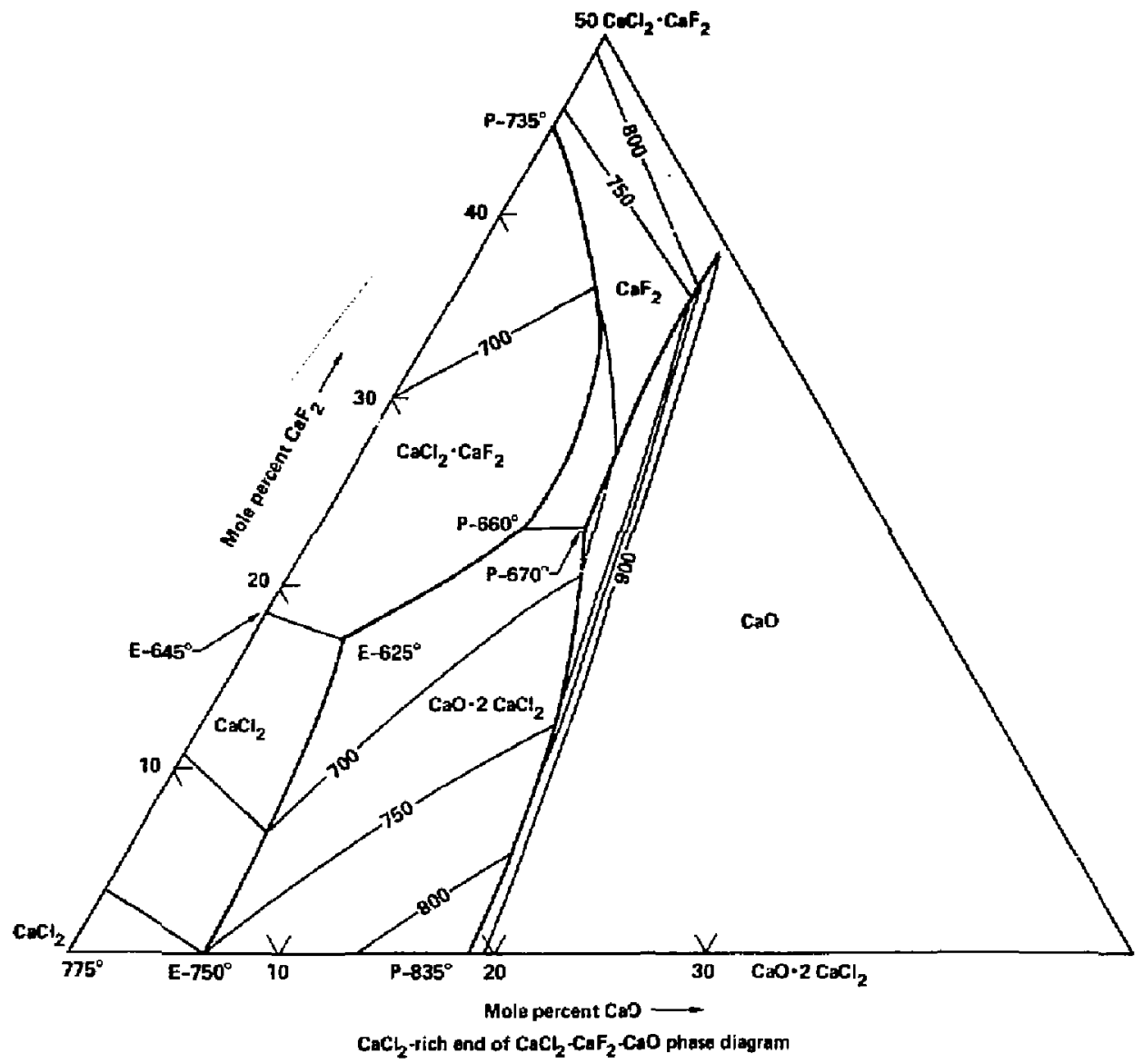

FIG. A-1. Partial ternary phase diagram for the $\mathrm{CaCl}_{2}$-rich side of the $\mathrm{CaCl}_{2}-\mathrm{CaF}_{2}$-GaO system, Source: D. Tens, I. Johnson, and R. Fol son, $I_{\text {, of }}$ Chem. and Eng. Data, 14(2) (April 1969).

35 


\section{Extraction of Americium with Molten Salt}

All reactor-produced plutonium contains a mixture of several plutonium isotopes. The continuous decay of $241_{\mathrm{Pu}}(14.8-\mathrm{y}$ half-life) is the source of 241 Am. This i,gotope decays by alpha emission with the simultaneous emission of $60-\mathrm{kV}$ gamma $5 F \mathrm{ys}$ in $80 \%$ abundance. In order to minimize personnel exposure, this element is removed from the metal prior to fabrication.

Early experimental work in electrorefining demonstrated that americium could be partitioned between molten plutonium and a molten $\mathrm{N} \leftarrow \mathrm{Cl}-\mathrm{KCl}$ salt containing $\mathrm{Pu}^{+3}$ ions. It was also demonstrated that americium could be extracted from $\mathrm{Mg}-\mathrm{Zn}-\mathrm{Pu}-\mathrm{Am}$ alloys with immiacible molten magnesium chloride salts. Work was undertaken at Rocky Flats to study the extraction of: americium from molten plutonium by contacting with molten NaCl-KCl salt coutaining a few percent of $\mathrm{MgCl}_{2}$.

A production process has evolved from this original work and is now used for extracting americiun from kilogram amounts of plutonium matal. This process is based upun equilibrium partitioning (by oxidation-reduction reactions) of americium and plutonium between the molten chloride salt and the mclten plutonium phase. The cheidisery of this process is shown by the following reactions:

$$
\begin{array}{ll}
\mathrm{Pu}+3 / 2 \mathrm{MgCl}_{2}+\mathrm{PuCl}_{3}+3 / 2 \mathrm{Mg} & -2.4 \mathrm{KCal} \\
\mathrm{Am}+\mathrm{PuCl}_{3} \rightarrow \mathrm{AmCl}_{3}+\mathrm{Pu} & -25.8 \mathrm{KCal} \\
\mathrm{Am}+3 / 2 \mathrm{MgCl}_{2}+\mathrm{AmCl}_{3}+3 / 2 \mathrm{Mg} & -28.2 \mathrm{KCal}
\end{array}
$$

The free energies of formation for the actinide compounds above are given by the following:

$\begin{array}{lc}\text { Compound } & \Delta G @ 1000 \mathrm{~K} \text { (KCal per gram-atom of chlorine) } \\ \mathrm{AmCl}_{3} & -67.0 \\ \mathrm{PuCl}_{3} & -58.4 \\ \mathrm{MgCl}_{2} & -57.6\end{array}$

The thermodynamic activity equilibrium constant $(\mathrm{Ka})$ is expressed in terms of wole fraction $(X)$ and activity coefficient $(\gamma)$ by the following equation: 


$$
x_{\mathrm{B}}=\frac{\left(\mathrm{x}_{\mathrm{AmCl}}\right)\left(\mathrm{\gamma}_{\mathrm{AmCl}}\right)\left(\mathrm{x}_{\mathrm{Mg}}\right)^{3 / 2}\left(\mathrm{\gamma}_{\mathrm{Mg}}\right)^{3 / 2}}{\left(\mathrm{x}_{\mathrm{Am}}\right)\left(\mathrm{Y}_{\mathrm{Am}}\right)\left(\mathrm{x}_{\mathrm{HgCl}}\right)^{3 / 2}\left(\gamma_{\mathrm{HgCl}_{2}}\right)^{3 / 2}}
$$

The term $\frac{\mathrm{XAmCl}_{3}}{\mathrm{X}_{\mathrm{Am}}}$ is defined as the distribution coefficient ( $\mathrm{D}_{\mathrm{Am}}$ )

and is simply the ratio of the mole fraction of $\mathrm{AmCl}_{3}$ in the salt to the atom fraction of Am in the metal.

The activity coefficients in the above equation may be determined by obtaining experimental data for $D_{A m}$, and relating $k_{a}$ to the free energy change for the reaction using the equation $\Delta G_{F}=-R T$. In $K$.

In laboratory work, the following closely related, but not identical, relationship is used to determine the partition value between phsses:

$$
\mathrm{K}_{\mathrm{d}}=\frac{\text { conc. of } \mathrm{AmCl}_{3} \text { in salt phase }}{\text { conc. of Am in setal phase }} \text {. }
$$

By conver tion, the above ratio is usually expressed in weight percent instead of mole fractions. For extraction work, the term $\alpha$ is used for the extraction factor and is related to $k_{d}$ in the following manner:

$$
\alpha=\left(K_{d}\right)\left(\frac{S}{m}\right)(F)(\beta),
$$

where

$$
\begin{aligned}
\alpha & =\text { extraction factor }=\frac{\text { Wt. of solute in salt phase }}{\text { Wt. of solute in metal phase }} \\
\mathrm{K}_{\mathrm{d}} & =\text { distribution coefficient (rs defined above) } \\
s / \mathrm{m} & =\text { salt-tu-metal ratio by weight } \\
\mathrm{F} & =\text { fraction of equilibrium attained } \\
\mathrm{B} & =\text { effects of side reactions }
\end{aligned}
$$

For a multistage countercurrent extraction operated in true equilibrium without :ide reactions, the partitioning of a solute into the metal phase ( $f_{\text {m }}$ ) and the galt phase $\left(f_{s}\right)$ is defined as follows: 


$$
f_{\text {in }}=\frac{(c-1)}{\left(\alpha^{n+1}\right)-1} \quad f_{s}=1-f_{m}
$$

Where $n=$ number of countercurrent stages.

Present production processes use two-stage countercurrent extraction to Iemove americium from molten plutoniun with magnesiun chloride-based salts. Both 35 mole $\mathrm{Z} \mathrm{NaCl} \mathrm{-} 35$ mole $\% \mathrm{KCl}$ - 30 mole $\mathrm{KgCl} \mathrm{Mg}_{2}$ and 50 mole \% NaCl-26 mole $z \mathrm{CaCl}_{2} \rightarrow 24$ mole $z \mathrm{MgCl}_{2}$ are used for americium extraction. The -hove salt will extract $90 \%$ of the americium present when a salt-to-metal mase-ratio of 0.06 is used in a two-stage countercurrelit extrattion.

The $\mathrm{Ara}$ and $\mathrm{Pu}$ are recovered from the $\mathrm{NaCl}-\mathrm{CaCl}_{2}-\mathrm{MgCl}_{2}$ oalt by contact with liquid crlcium metal at approximately $850^{\circ} \mathrm{C}$ in a bach extractar. The calcium reduces $\mathrm{AmCl}_{3}, \mathrm{PuCl}_{3}$, and ${ }_{3} \mathrm{Cl}_{2}$ to form a 50/50 mole $\%$ NaCl- $\mathrm{CaCl}_{2}$ salt phase and a molten Am-Pu-Mg-Ca alloy that is imiacible in the above salt. After cooling, the netal phase is cleaved away from the salt phase and the salt phase is analyzed. Little, if any, Am or Pu remains in the salt phase, and the salt residues can be discarded to waste. Metal recovery begins by evaporating magnesium and calcium from the regidual metal button at about $800^{\circ} \mathrm{C}$ in yacuum. The americiuir can then be distilled away from the plutonium in a vacuum still operated at $1200^{\circ} \mathrm{C}$, using yttria ceramic vessels to contain the molten metal fraction. The bottom fraction contains the plutoniun that is recycled back into the main plutonium stream.

\section{Plutonium Electrorefining}

The first publication related to plutonium electrochemistry dates bask to Manhattan Project work at Los Alamos. Improvements have continued, and in 1962 a production process ( $3-\mathrm{kg}$ scale) for routine production of $>99.9 \%$ pure metal was reported. Recent developments at $\mathrm{t}$. $s$ Alamos have expended the capacity of the electrorefining cells to about $6 \mathrm{~kg}$ per batch, with a cycle time of five days.

The principle of the electrorefining process is basically simple: plutonium is oxidized at a liquid metal anode contai,ing impure meta? feed and the resulting $\mathrm{Pu}^{+3}$ ions are transported through molten salt to a cathode where pure metal is produced. The transport salt is ugually eutectic $\mathrm{NaCl}-\mathrm{KCl}$, but $\mathrm{NaCl}-\mathrm{CaCl}_{2}$ can also be used. As liquid plutonium metal builds 
up on the cathode, it drips off into an annular channel surrounding the anode cup where it coalesces into a -.onl of metal and is recovered after the cell is cooled. The entire chemical process is performed in a molten salt bath. The basis chemistry of the electrorefining technique is as follows:

$$
\begin{array}{ll}
\text { Anode reaction: } & \mathrm{Pu}_{(\ell)} \text { impure }+\mathrm{Pu}^{+3}+3 \mathrm{e}^{-} \\
\text {Cathode reaction: } & \mathrm{Pu}^{+3}+3 \mathrm{e}^{-}+\mathrm{Pu}_{(\ell)} \text { pure }
\end{array}
$$

$\mathrm{PuCl}_{3}$ must be added to the cell prior to operation to maintain a high concentration of $\mathrm{Pu}^{+3}$ ions in the salt phase. This $\mathrm{PuCl}_{3}$ also scts 8.8 a salt-phase buffer to prevent dissolution of trace impurities is the metal feed by forcing the anode equilibrium to favor production (retention) of trace jmpurities as metals, instead of permitting oxidation of the impur:ties to ions. Metallic impurities in the feed fall into two classes, those nore electropasitive and those les's electropositive than plutonium. Because the ce11 is operated at temperatures above the melting point of all feed components, and both the liquid anode and salt are well raixed by a mechaical stirrer, chemical cyulilibrium is established between all impurities and the plutonium in the salt even before curxent is applied to the cell. Thus, impurities more electropositive than the liquid plutonium anode will be oxidized by $\mathrm{Pu}^{+3}$ and taken up by the salt phase, while inpurities in tire electrolyte salt less electropositive than plutonium will be reduced by plutonium metal and collected in the anode. Those impurities less electropositive than plutonium that are already present in the molten anode will remain in the anode. The extent of these reactions will be aetermined by the reaction-free enexgy and concentration for each of the impurities in the molten anode/electrolyte salt system. Americium can be usea as, an example of a very electropositive impurity:

$$
\mathrm{Am}(\text { metal })+\mathrm{PuCl}_{3}(\mathrm{salt})=\mathrm{ArCl}_{3}(\text { salt })+\mathrm{Fu} \text { (metal) }
$$

When current is passed through the cell, the concentration of impurities in the product obtaired at the cathode will depend upon their concentration in the salt. If equilibrium conditions exist in the cell, the following equation applies : 
$\frac{(\mathrm{Am})}{(\mathrm{Pu})}$ metal product $=\frac{2}{\mathrm{~K}} \frac{\left(\mathrm{AmCl}_{3}\right)}{\left(\mathrm{PuCl}_{3}\right)}$

Where the parenthesis refer to the chemical activities of the reactants and $\mathrm{K}$ is the equilibrium constant for the previaus equation. Similar considerations apply to the oxidation of less electropositive impurities from the anode when a currer: $i$ is passed through the cell. Thus, for the case of iros impurity in the snode, the ragction

$3 \mathrm{Fe}+2 \mathrm{PuCl}_{3}=2 \mathrm{Pu} \div 3 \mathrm{FeCl}_{2}$

favors the production of iron wetal instead of ferrous ion because the free-energy change for the reacticn is $+96 \mathrm{kCal}(+96 \mathrm{kCal}$ ic equivalent to an equilibrium constant of $1 \times 10^{21}$ at $1000 \mathrm{~K}$ ).

The composition of the salt electrolyte in the cell does not change during the electrorefining cycle so long as the driving potential of the cell i.s kept below the decomposition voltage of the electrolyte. The following $g$ 'res the decomposition potential of ncresl components of the electrolyte:

$\begin{array}{cc}\text { Chloride salt } & \text { Decomposition patential at } 800^{\circ} \mathrm{C} \\ \mathrm{CaCl}_{2} & 3.32 \\ \mathrm{KCl} & 3.44 \\ \mathrm{NaCI} & 3.25 \\ \mathrm{MgCI}_{2} & 2.46 \\ \mathrm{PuCl}_{3} & 2.40\end{array}$

Because the exergy required to strip the electrons from plutonium metal at the anode is exactly matched by the energy returned at the cathode, the potential required by the process is only that required to overcome time-invariant $\left(I^{2} R\right)$ losses in the cell circuit and time-depender: resistance (electrode polarization).

Polarization of the anode occ:rs after most of the plutonium is transferred across the ceil, and impurities constitute a large percentage of the snode. The reason for this can be demonstrated by using the ctise of delta plutonium alloy feed. Delta alloy conteins wl wt.\% gallium. The normal operating temperature of the electrorefining cell is $750^{\circ} \mathrm{C}$, and at this temperature the delca alloy melto to form a liyuid phase. 
As electrorefining proceeds, plutonium is aelectively removed from the anode and the compositior of the anode becomes enriched in gallium, At approximately 18 mole \% gallium, the lower density eta phase Pu begins to form (at $750^{\circ} \mathrm{C}$ ) and a mixture of solid eta phase and liquid is formed at the anode surface (eta phase floats on the iiquid plutonium phase). The back-EMF of the cell gradually increases as the eta phase is formed. Vigorous stirring exposes liquid plu onium and permits oxidation to proceed at the anode surface, but at 25 mole \% gallium, the anode solidifies. Consinued operation of the cell oxidizes gallium in the ratio of the composition of the solid anode.

To prevent the passage of impurities, the back-EMF of the cell is monitored at frequent intervals. The current to the electrodes is turned off, and the voltage of the cell is measured. When the back-EMF reaches a predetermined value, opexation of the cell is terminated, and the cell is allowed to cool. The cathode product, which consists of very pure plutonium metal, is recovered from the solidified salt mass by breaking the ceramic vessel and brushing the ring free of adhering salt. The product ring typically amounts to about $85 \%$ of the original mass of the anode feed metal. The impurity level of the cathode product from electrorefining is usually below normal spectroscopic detectability levels if the cell is run at anode current densities of 0.60 daps per aq. ctu. rr less.

The level of purification that can be achieved from impurities by the electrorefining process is directly related to the free-energy formation of the chloride salt and of each impurity present in the feed metal, as discussed above.

The basic electrorefining process is now being used on a production scale for the purification of nonspecification plutoniun metal. The technology is sufficiently well deweloped to pertait 24-h unattended speration of the electror:fining cells, and the quality of the product metal is highly consistent. This technology is rapidly replacing aqueous chemistry for plutoniuin metal purification.

\section{Salt Transport Processes}

The term "salt transport" refers to a techrique whereby a metal bic solute is transferred selectively from one liquid alloy (donor) to another liquid alloy (acceptor) by circulating a multen salt between the two alloys. The transfer cakes place through oxidation of the solute by the salt at the donor alloy and its subsequent reduction by the acceptor alloy. 
A salt transport procedure for uranium is illustrated schematically in Fig. A-2. Metallic uranium, which is initially present in the donor alloy, is oxidized and extracted into the transport salt.

$$
\begin{aligned}
& \mathrm{U} \text { (donor alloy) }+\mathrm{MBCl}_{2} \text { (galt)+ } \\
& \operatorname{UCL}_{3}(\mathrm{gaIt})+\mathrm{Mg}(\text { donor alloy) }
\end{aligned}
$$

Zixconiun and all the elements below it in Table A-I should be separated readily from uranium and plutonium by a process in which the uranium and plutonium are extracted into a molten salt.

The difference in the distribution behavior of two elements, $M_{a}$ and $M_{b}$, is expressed as a separation factor, $a$ :

$$
a=\frac{\mathrm{D}_{\mathrm{a}}}{\overline{\mathrm{V}}_{\mathrm{M}_{\mathrm{b}}}}
$$

where $D_{M}$ is the distribution of $M$ between the metal and salt phases:

$$
D=\frac{X_{M C 1}}{X_{M}}
$$

The equilibrium constant, $\mathrm{K}_{\mathrm{a}}$, is related to the standard free-energy change, $\Delta G^{\circ}$, for Reaction 1 by the equation:

$$
\text { -RT 1n } K_{2}-\Delta G^{\circ}=\Delta G E_{\mathrm{MgCl}}^{\circ}
$$

Uranium in solution in the acceptor and donor alloys is equal to the ratio of the distribution coefficients of uranium for each alloy and the salt. The separation factor is strongly dependent on the composition of the liquid alloy and, to a lesser extent, on the temperature and on the compusition of the moIten salt. 


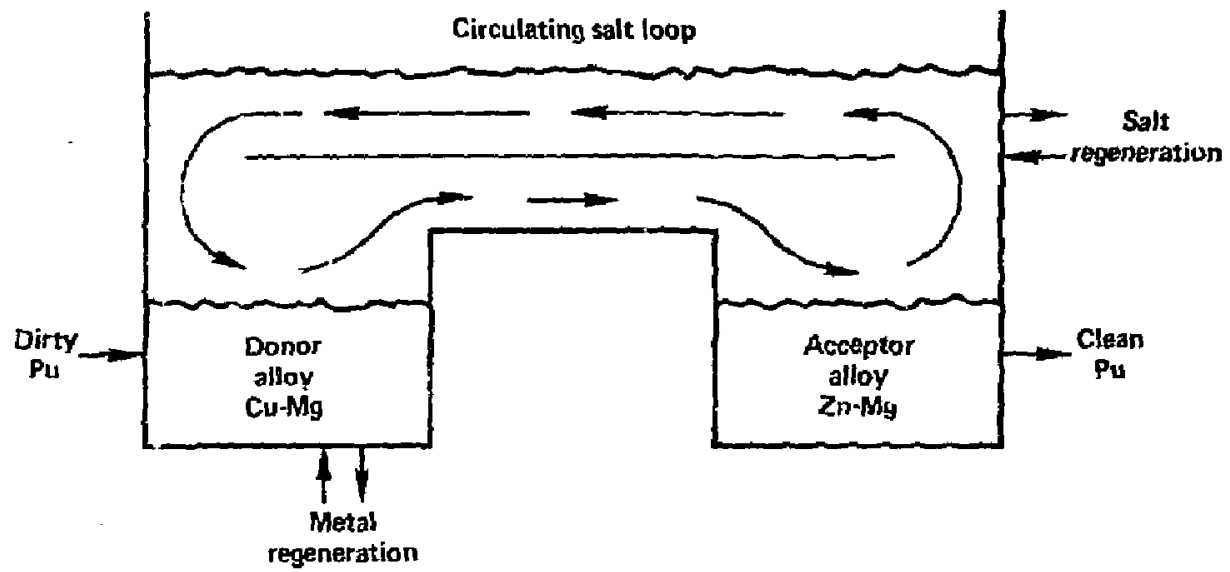

FIG. A-2, salt transport. 
Table A-1. Standard free energies of formation of chlorides at $1000^{\circ} \mathrm{K} . \star$

\begin{tabular}{|c|c|c|c|}
\hline $\mathrm{MCl}_{\mathrm{n}}$ & $\begin{array}{c}-\Delta G f \\
(k C a 1 / g-e q u i v . ~ C l)\end{array}$ & $M C 1_{n}$ & $\begin{array}{c}-\Delta G f \\
(\mathrm{kCal} / \mathrm{g}-\mathrm{equiv}, \mathrm{Cl})\end{array}$ \\
\hline $\mathrm{BaCl}_{2}$ & 83.6 & $\mathrm{HgCl}_{2}$ & 57.7 \\
\hline $\mathrm{CsCl}$ & 82.6 & $\operatorname{vel}_{3}$ & 54.0 \\
\hline $\mathrm{RbCl}$ & 82.5 & $\mathrm{MnCl}_{2}$ & 42.2 \\
\hline LiCl & 78.8 & $\mathrm{ZrCl}_{2}$ & 34.2 \\
\hline $\mathrm{KCl}$ & 81.6 & $\mathrm{ZnCl}_{2}$ & 34.1 \\
\hline $\mathrm{SrCl}_{2}$ & 80.8 & $\mathrm{CrCl}_{2}$ & 32.8 \\
\hline $\mathrm{SmCl} 1_{2}$ & 80.0 & $\mathrm{CdCl}_{2}$ & 30.4 \\
\hline $\mathrm{EuCl}_{2}$ & 79.0 & $\mathrm{FeCl}_{2}$ & 26.3 \\
\hline $\mathrm{CaCl}_{2}$ & 76.7 & Cucl & 22.0 \\
\hline KaCl & 76.2 & $\mathrm{NiCl}_{2}$ & 18.6 \\
\hline $\mathrm{LaCl}_{3}$ & 67.0 & $\mathrm{NbCl}_{5}$ & 11.4 \\
\hline $\mathrm{PrCl}_{3}$ & 66.3 & $\mathrm{MoCl}_{2}$ & 8.0 \\
\hline $\mathrm{CdCl}_{3}$ & 66.3 & $\mathrm{TeCl}_{3}$ & 7.4 \\
\hline $\mathrm{NaCl}_{3}$ & 64.2 & $\mathrm{PdCl}_{2}$ & 5.3 \\
\hline $\mathrm{YCl}_{3}$ & 61.2 & RhCl & 1.4 \\
\hline PuCl_ & 58.4 & $\mathrm{IRuCl}_{3}$ & 0.3 \\
\hline
\end{tabular}

* Source: J. B. Knighton, "pyrochemical Processing of LWR and LMFBR Fuels by the Salt Transport Method," Akademische Verlagsgesellschaft, Wiesbaden, 1979. 
When the trapsport salt containing the UCl ${ }_{3}$ is contacted with the acceptoi alloy, the reverse reaction takes place:

$$
\begin{aligned}
& \mathrm{UCl}_{3}(\mathrm{salt})+\mathrm{Mg}(\text { acceptor alloy })+ \\
& +\mathrm{V}(\mathrm{acceptor} a l l o y)+\mathrm{MgCl}_{2}(\mathrm{sal} t)
\end{aligned}
$$

Therefore, the net reaction is:

$$
\begin{aligned}
& \mathrm{U}(\text { donor alloy })+\mathrm{Mg}(\text { acceptor a! loy })+ \\
& +\mathrm{V}(\text { acceptor a11oy })+\mathrm{Mg} \text { (donor alloy). }
\end{aligned}
$$

Magnesium chloride consumed at the donor alloy by oxidation of uranium and piutonium is regenerated at the acceptor alloy by magnesium reduction of $\mathrm{UCl}_{3}$ or $\mathrm{PuCl}_{3}$. Thus, the beginning and end salt corposition is constant in the salt transport operation. For each mole of uranium transferrea from the donor alloy to the acceptor alloy, 1.5 moles of magnesiut are transferred in the opposite direction. The increasing concentration of magnesium in the donor 3 lloy and magnesium depletion in the acceptor alloy must be taken into account in the design of a practical process.

Whes the reduction reaction has reached equilibrium, both alloys are in equilibrium with the transport salt, and the ratio, $R$, of uranium in solution in the acceptor and donor alloys is equal to the ratio of the distribution coefficients of uranium for each alloy and the salt. 
Christensen, D.C , and Mullins, L.J., Salt Stripping, a Pyrochemical Approach to the Recovery of Plutonium Electrorefining Salt Residues, Los Alamos National Laboratory, Log A1smog, NM, IA-9464-MS (1982).

Felt, R.E., A Pyrochemical Process for the Reduction of Plutonium Dioxide to Metal, Atlantic Richfield Hanford Co., Hanford, WN, ARH-1198 (July 1969).

Knighton, J.B., and Steunenberg, R.K., "Distribution of Transuranium Elements Between Magnesium Chloride and 2inc-Magnesium Alloy," J. of Inorganic and Nuc. Chem, 27, 1457-1462 (1965).

Rnighton, J.B., Auge, R.G., and Berxy, J.W., Molten Salt Extraction of Americium from Molten Plutonium Metal, Rocky Flats Plant, Golden, Co, RPp-2365 (1976).

Long, J.L., and Perry, C.C., "The Holten Salt Extraction of Arericium from Plutonium Metal," Nuc. Metal 15, 385 (1969).

Moseley, J.D., strickland, W.R., Deming, W.D., Auge, R.G., and Brown, J.C., unpublished Rocky Flats Plant data, Golden, Co; also RFP-1472 (1970), pp. 13-14.

Mullins, L.J., and Foxs, C.L, , Direct Reduction of $238_{\text {Pu. }}$ to Metal, Los Alamos National Laboratory, Los Alamos, NM, LA-9073 (1982).

Muliing, L.J., and Leary, J.A., "Fused Salt Electrorefining of Holcen Plutonium by the LAMEX Process," I and EC Process Design and Development 4 , 394 (October 1965),

Mullins, L.J., Leary, J.A., Morgan, A.E., and Maraman, W.J., Plutonium Electrorefining, Los Alamos National Laboratory, Los Alamos, MH, LA-2666 (1962). 
Mullins, L.J., Morgen, A.M., Apgar, S.A., III, and Christencen, D.C., Six-Kilogram Scale Electrorefining of Plutonium Metal, Los Alamos :tacional Laboratory, Los Alawos, MM, LA-9469-MS (1982).

Oetting, F.L., "The Themical Thermodynamic Properties of Plutonium Compounds," Chemical hiseviews 67, 261 (1967).

Schweikhardt, R.E. : "Metal-Salt Reactions in Molten Systems of Plutonium Metal and $\mathrm{NaCl}, \mathrm{NaCl}-\mathrm{KCl}$, and $\mathrm{NaCl}-\mathrm{KCl}^{-} \mathrm{KgCl}_{2}$," thesis, Univ. of Denver (August 1966).

Gade, Warren Z., and Wolf, T., "Preparation of Massive Plutonium Mecal Directly from Its Oxides," J. Nuc1. Sci. and Technol. 6(7), 402-407 (1969).

Wenz, D.A., Johnson, I., and Wolson, R.D., "CaCl ${ }_{2}$-Rich Region of the $\mathrm{CaCl}_{2}-\mathrm{CaF}_{2}-\mathrm{CaO}$ System," J. Chem. Eng. Data 14(2), 250-252 (1969). 


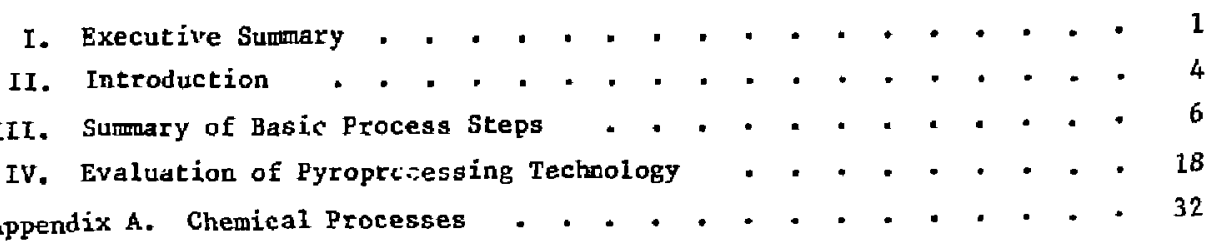

\section{F IGURES}

1. Metal production line +. + . . . . + . . . . . . . 10

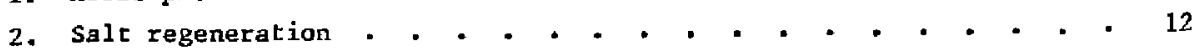

3. 2PPR fuel processing--simplified process flow diagram • • • • • 1h

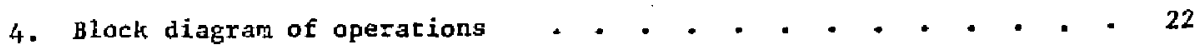

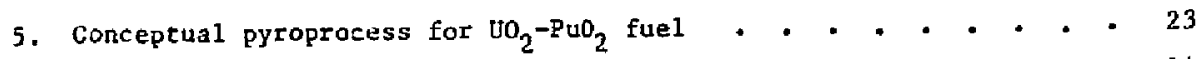

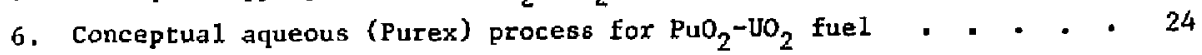

A-1. Partial ternary phase diagran for the $\mathrm{CaCl}_{2}-\mathrm{rich}$ side of the

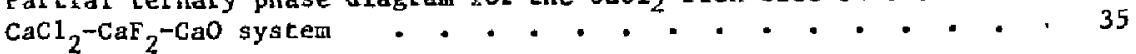

A-2. Salt transport . . . . . . . . . . . . . . . . . . 43

TABLE S

A-1. Standard free energies of formation of chlorides at $1000^{\circ} \mathrm{K}$. . . 44

\section{DHSCLALMER}

This repor was prepared as an account of work sponsored by an agency of the United States Government. Neithor the United States Goverrment nor any agency thereof, nor any of thcir employees, makes any warranty, express or implied, or assumes any legal liability or responsibility for .he acruracy, crmpleteness, or usefulness of any information, apparalus, produrt, or process disclosed, ar represents that its use would not infringe privately ownod rights. Reference hercin to any specific commercial producl, process, or service by trade name, trademark. manufacturer, or atherwise does not necessarily constitute or imply its endorsement, recommendation, or favoring by the Uniled States Government or any agency thereof. The viex : and opinions of authors expressed herein do not necessarily state of rellecl thase of tice United States Government or any agency therool. 